\title{
Institutional Investors and Accounting Restatements
}

\author{
Paul Hribar \\ Henry B. Tippie College of Business, University of Iowa \\ Iowa City, IA 52242-1994, United States \\ Tel: 1-319-335-1008 E-mail: paul-hribar@uiowa.edu
}

Nicole Thorne Jenkins

Owen Graduate School of Management, Vanderbilt University

$40121^{\text {st }}$ Avenue South, Nashville, TN 37203, United States

Tel: 1-615-343-0553 E-mail: Nicole.Jenkins@owen.vanderbilt.edu

Juan Wang (Corresponding author)

School of Accountancy, Singapore Management University

60 Stamford Road, Singapore 178900, Singapore

Tel: 65-6828-0986 E-mail: juanwang@smu.edu.sg

\begin{abstract}
This paper investigates the role that institutional investors play in the market reaction to accounting restatements. We show that transient institutional investors, defined as institutions with short investment horizons and high portfolio turnover, significantly reduce their holdings in a restating firm at least one quarter prior to the quarter of the restatement announcement. This result holds after controlling for factors such as return momentum, unexpected earnings, size, book-to-market, and the portfolio weight of the firm to the institution. Second, using previously identified predictors of earnings manipulation, we show that institutional investors react most negatively to an increase in the days sales in receivables and high accruals. Finally, we demonstrate that the market reaction to accounting restatements for firms with higher levels of transient institutional ownership is more negative in the period prior to the restatement announcement. Taken together, these results suggest that institutional investors act as though they partially anticipate potential accounting irregularities and adjust their holdings downward prior to the restatement announcement.
\end{abstract}

Keywords: Institutional investors, Accounting restatements

JEL Classifications: G30, M41 


\section{Introduction}

Recent scandals in accounting have led to a heightened interest in both the causes and consequences of accounting restatements (see, among others, Palmrose and Scholz, 2004; Hribar and Jenkins, 2004). One of the most striking findings from this set of studies is the substantial loss in market value when a firm restates earnings, which averages $9 \%$ across all restatements and over $20 \%$ when the restatement is deemed fraudulent or initiated by the auditor (Palmrose, Richardson, and Scholz, 2004). Despite the number of studies that document the overall market reaction to the restatement, however, little evidence exists on how different types of investors anticipate and respond to this event.

In this paper, we focus on institutional investors and examine the role that institutional investors play in determining the market reaction to accounting restatements. In particular, we address three research questions. First, we ask whether actively trading institutional investors reduce their holdings prior to the restatement announcement. Prior research has documented the role of institutional investors as information intermediaries and their sophistication in processing accounting information. For example, institutional investors serve as arbitrageurs and mitigate documented mispricing in equity stocks (e.g. Bartov, Radhakrishnan, and Krinsky, 2000; Collins, Gong, and Hribar, 2003). The trading behavior of institutions also appears to predict corporate events such as breaks in consecutive positive earnings surprises (Ke and Petroni, 2004) and dividend increases (Amihud and Li, 2006). However, studies that have attempted to identify the source of institutional investors' information advantage suggest that institutional investors' information advantage is mainly obtained from private information disclosed from firm management, rather than from institutions' superior ability to process public information. In contrast, an accounting restatement represents an event that managers are ex-ante unlikely to share with analysts and institutions in private conversations. Therefore, it remains an open question as to whether institutional investors will be able to predict this event.

Second, we ask whether there is evidence that the change in institutional holdings is related to financial statement indicators that have been shown to predict earnings manipulation. Using the factors documented by Beneish (1999) to be associated with the likelihood of earnings manipulation, we examine how these earnings manipulation predictors relate to changes in institutional holdings prior to an accounting restatement. Identifying which earnings manipulation predictors are associated with changes in institutional holdings provides evidence about the signals that actively trading institutional investors use in adjusting their holdings of a company. It also provides additional assurance that reductions in holdings prior to the restatement are, at least partially, information-based.

Third, we ask whether the presence of actively trading institutional investors affects the price formation process surrounding the restatement announcement. We compare the preannouncement period returns for firms with different levels of institutional ownership to determine whether the prices of firms with higher levels of institutional ownership reflect the bad news associated with a restatement in a more timely fashion. Prior research suggests that the presence of institutional investors speeds the process at which information gets impounded into price (El-Gazzar, 1998; Jiambalvo, Rajgopal, and Venkatachalam, 2002; Ayers and Freeman, 2003; Balsam, Bartov, and Marquardt, 2002). If actively trading institutional investors acquire information such that they are able to partially anticipate an impending restatement, then we expect that the stock price of firms with higher levels of actively trading institutional ownership will reflect the information content of the accounting restatement more timely in the pre-announcement event period. 
In all of our tests, we use Bushee's (2001) classification of institutions based on institutional investors' past investment behavior. We focus on 'transient' institutional investors, as they are the institutions that actively manage their portfolios and trade frequently over short-term. As such, transient institutions' trading behavior is most likely to reflect short-run, information-based trading patterns (Collins, Gong, and Hribar, 2003; Ke and Ramalingegowda, 2005).

We examine a sample of 364 restatements from 1997 through 2002 and summarize our major findings as follows. First, we find that actively trading institutional investors (i.e. transient institutions) reduce their holdings in restating firms at least one-quarter prior to the quarter of the restatement announcement. This result holds after controlling for the average change in institutional holdings, the portfolio weight of the restating firm to the institutions, return momentum, seasonal change in earnings, size, book-to-market ratio, and industry and year fixed effects. We find no evidence that other groups of institutions anticipate restatements and reduce their holdings early to avoid the negative returns associated with restatements. Further, of the factors that predict earnings manipulation, we find that institutional investors reduce their holdings in response to increases in days sales in receivables (i.e. a decrease in accounts receivable turnover) and to high accruals. Finally, we show that restating firms with high levels of transient institutional ownership exhibit more negative returns prior to the restatement announcement, relative to firms with low levels of transient institutional ownership. This finding is consistent with the notion that higher levels of holdings by actively trading institutional investors allow information to be incorporated into price in a more timely fashion.

This study makes the following contributions. First, this study adds to the literature on the information environment of institutional investors by showing that actively trading institutional investors can anticipate impending restatements. On the one hand, previous research finds that actively trading institutional investors are, on average, informed users of information (see, among others, Collins, Gong, and Hribar, 2003; Ke and Ramalingegowda, 2005). On the other hand, empirical evidence also suggests that actively trading institutional investors may not be as sophisticated as commonly thought; these institutional investors may merely chase return momentum or underperform market portfolios (see, for example, Cohen, Coval, and Pastor, 2005; Kacperczyk, Sialm, and Zheng, 2005). The finding in this study adds to this line of research by providing evidence on the ability of institutional investors to anticipate restatements. Although the magnitude of the advance trading makes it unlikely that the institutions actually have specific information about an impending restatement, the advance reduction in institutional holdings is consistent with institutional investors expecting bad news of some form.

The results further shed additional insight on the information source of institutional investors by showing that superior ability to process public information is likely the source of information advantage by institutional investors concerning restatement events. Previous work either assumes that institutional investors have information advantage without testing the information source (see, for example, Walther, 1997), or finds that institutional investors have information advantage because of private information disclosed from firm management (see, among others, Ke and Petroni, 2004; Bushee and Goodman, 2007; Ke, Petroni, and Yu, 2008). Our results provide evidence that the information advantage of institutional investors to anticipate a forthcoming restatement is likely attributable to institutions' superior ability to process public information related to restatements. 
Finally, our work has implication for research examining the role of total institutional ownership in market reactions around accounting events (e.g., Bartov, Krinsky, and Radhakrishnan, 2000; Ayers and Freeman, 2003). Our study underscores the importance of differentiating among institutions with various investment styles, and shows that the market reactions to restatement events vary cross-sectionally, based on the level of different institutional ownership and the ability of sophisticated investors to predict the restatement event.

The remainder of the paper proceeds as follows. The next section reviews the relevant literature. Section 3 discusses the sample selection and variable measurement, and provides descriptive statistics. Section 4 describes our research design and discusses the empirical results. Section 5 concludes.

\section{The Literature on the Information Advantage of Institutional Investors}

\subsection{Institutional Investors' Trading Behavior and Their Information Advantage}

Prior research documents that institutional investors have information advantage. With the advantage of private information gathering and/or public information processing, some institutional investors appear to engage in informed trading in response to future information. For example, institutional investors trade actively in anticipation of impending events, such as breaks in consecutive earnings increases (Ke and Petroni, 2004), future earnings implication of current accruals (Collins, Gong, and Hribar, 2003), future dividend increases (Amihud and $\mathrm{Li}, 2006$ ), and future abnormal returns around subsequent earnings announcements (Ali et al., 2004). There is also evidence that institutional investors acquire and strategically trade on predisclosure information. For example, El-Gazzar (1998) finds that the higher the institutional ownership, the smaller the market reaction to earnings releases, consistent with institutional investors acquiring predisclosure information and trading on this predisclosure information to mitigate the market response when earnings is announced. Bartov, Radhakrishnan, and Krinsky (2000) and Ke and Ramalingegowda (2005) both show that post-earnings-announcement drift is negatively correlated with institutional ownership, suggesting that institutional investors trade on the implication of current earnings surprises on future earnings. Balsam, Bartov, and Marquardt (2002) demonstrate that sophisticated investors, as measured by the level of institutional ownership, recognize accrual management prior to the release of 10-Qs and trade on the unexpected accruals before the 10Q filing date.

Building on prior research, this study directly examines the trading behavior of institutional investors prior to an accounting restatement. We use accounting restatements as our event for several reasons. First, accounting restatements represent economically significant events, associated with substantial loss in market value on the restatement date. Second, to the extent that these restatements involve an inappropriate application of GAAP that is reflected in past financial statements, it is reasonable to expect that a sophisticated investor would have a greater chance of identifying these firms through superior knowledge of financial statements and/or more resources to spend on analyzing the statements. ${ }^{1}$ Third, accounting restatements represent a setting where it is less likely that management would communicate this information to external shareholders such as institutional investors, as the restatements often

\footnotetext{
${ }^{1}$ For example, to the extent that a restatement involves accruals, a deeper understanding of the financial statement ratios and a detailed analysis might help identify potentially problematic accounting. Similarly, an understanding of earnings management incentives and the ability to identify 'red-flags' help identify situations where earnings manipulation is more likely to occur.
} 
are initiated by third parties (such as the auditor), and can involve fraudulent actions on the part of management. ${ }^{2} \mathrm{P}$ As a result, we believe that our setting is one in which the informed trading by institutional investors is most likely to be explained by superior processing of public information rather than by private information acquisition.

Institutions exhibit significant variation in investment style, reflected in portfolio diversification and portfolio turnover (e.g., Bushee, 1998, 2001; Bushee and Noe, 2000). For each year, Bushee (2001) classifies institutional investors into one of the three groups: transient (TRANSIENT), dedicated (DEDICATED), and quasi-indexing (QIX), using both factor analysis and cluster analysis based on each institutional investor's past investment behavior (for the institutional classification scheme, refer to Appendix II Characteristics of different types of institutional investors). Following Bushee (1998, 2001), we analyze transient, dedicated and quasi-indexing institutions, respectively. Transient institutions are characterized as having short investment horizon and high turnover to maximize short-term profits. Dedicated institutions are committed to providing long-term capital and having more concentrated portfolio holdings in a limited number of firms. Quasi-indexers generally follow a passive, buy-and-hold strategy with diversified holdings. As such, both dedicated and quasi-indexing institutions are characterized as having less active portfolio management than transient institutions. While we do not expect that these institutions are less sophisticated than transient institutional investors, their investment styles are such that they are less likely to be actively engaged in information processing to make short-term trading decisions. ${ }^{3}$ Therefore, if any evidence exists that institutional investors anticipate restatements, we expect it to be greatest among transient institutional investors. This classification scheme increases the power of our empirical tests, because it allows us to focus on the set of institutions that are most likely to exhibit short run, information-based trading (i.e., transient institutional investors). However, our empirical tests include analysis on total institutional holdings as well as dedicated and quasi-indexing institutions, respectively, in order to provide a contrast concerning how each type of institutional investors behaves surrounding the restatement announcement quarter.

\subsection{Institutional Investors and Price Formation}

In order to examine the role of institutional investors in price formation, we analyze the market reaction surrounding the restatement and examine the extent to which institutional investors accelerate the incorporation of restatement related information into stock price. Prior research suggests that variation in predisclosure information environment comprises one source of the cross-sectional differences in the market reactions to earnings related information. For example, El-Gazzar (1998) finds that institutional ownership is negatively associated with the market reaction around earnings releases, consistent with institutional investors acquiring predisclosure information and mitigating the market response when earnings information is released. In a similar vein, Jiambalvo, Rajgopal, and Ventkatachalam (2002) show that firms favored by institutional investors incorporate future earnings into prices earlier than other firms. Ayers and Freeman (2003) find a similar result as Jiambalvo, Rajgopal, and Ventkatachalam (2002) after controlling for analyst following, and show that returns from high-institutional-ownership portfolios have a greater price lead by six months

\footnotetext{
${ }^{2}$ Even if management was willing to communicate this type of news to institutional investors, it is reasonable to expect that the dedicated institutions would have access to firm management that is as good as or better than transient institutions. Because we find that dedicated investors do not reduce their holdings in advance of the restatement, this suggests that dedicated institutional investors have not been forewarned of the restatement.

${ }^{3}$ We thank Brian Bushee for providing the institutional classifications.
} 
over those from low-institutional-ownership portfolios. Taken together, these studies indicate that information acquisition by institutional owners accelerates the impounding of earningsrelated information into price. Building on this literature, if transient institutional investors can partially anticipate the restatement, we expect that having a greater transient institutional ownership will increase the amount of information to be impounded into price prior to the actual restatement announcement. Put it another way, we predict that firms with high levels of transient institutional ownership will exhibit more negative stock returns in the prerestatement-announcement period, relative to firms with low levels of transient institutional ownership.

The returns-based analysis also provides a necessary complement to the institutional holdings-based tests because institutional holdings are only tabulated on a quarterly basis. For example, if a restatement happens in the third month of a given quarter, our institutional holdings tests will only capture reductions in holdings that occur more than two months before (i.e., we find that transient institutions reduce holdings at least one quarter prior to the restating quarter). By examining the daily returns around the actual restatement announcement conditional on institutional holdings, we are able to capture the impact of institutional trading (i.e. a change in the stock price) that occurs closer to the event date, with no need to measure the change in institutional holdings on a daily basis. Finally, finding a more negative market reaction to the accounting restatement in the pre-event period for firms with higher levels of institutional ownership provides more assurance that the tests on changes in institutional holdings do not just capture uninformed trading patterns related to return momentum, and are at least partially due to information-based trading.

As mentioned above, our empirical tests consider each group of institutions classified by investment style (i.e., transient, dedicated and quasi-indexing institutions). These additional tests are performed to demonstrate that the hypothesized phenomena exists primarily for firms with high levels of transient institutional ownership, and that different types of institutional ownership lead to different price formation paths.

\section{Sample Selection and Variable Measurement}

\subsection{Sample Selection}

Accounting restatement data are obtained from the U.S. General Accounting Office (GAO, 2003), which contains accounting restatements announced in the period January, 1997 to June, 2002. The General Accounting Office (2003) constructed a sample of 919 restatements containing firms that are required to restate their financial statements because of material accounting irregularity and/or frauds. ${ }^{4}$ The GAO (2003) database is comprised of the name, ticker symbol, and exchange of the restating firm, the restatement announcement date, the number of shares outstanding, the initiator of the restatement, and the reason(s) for the restatement. 5

\footnotetext{
4 The GAO (2003) states "we focused on financial restatements resulting from accounting irregularities, including so-called aggressive accounting practices, intentional and unintentional misuse of facts applied to financial statements, oversight or misinterpretation of accounting rules, and fraud. --As a general rule, we also excluded restatements resulting from accounting policy changes because they did not necessarily reveal previously undisclosed, economically meaningful data to market participants."

${ }^{5}$ We do not include accounting restatements announced after June 2002, because these restatements are more likely to result from the regulatory changes required under the Sarbanes-Oxley act (the SOX) (Chen, Cheng, and Lo, 2009). Consistent with this view, prior research documents that the post-2002 restatements have a small impact on net income of the restating firms (e.g., Plumlee and Yohn, 2009).
} 
We obtain data on institutional ownership from Thomson Financial CDA/Spectrum dataset. ${ }^{6}$ Financial statement data are collected from CRSP/COMPUSTAT Merged - Industrial Quarterly. Returns data are collected from CRSP daily stock returns file for NYSE, AMEX, and NASDAQ firms.

We mitigate the confounding events following the two procedures. First, to rule out earlier public announcements about an impending restatement as the source of any pre-restatement trading, we search Factiva starting with the date given in the GAO (2003) database, and look back six months earlier for any articles, press releases, etc. that might indicate the possibility of a restatement. For those with an earlier date, we use the date of the earliest article in the Factiva dataset related to the restatement as our event date. This affects a total of 45 observations. Second, we remove the firms whose restatement announcement date is in the window $(-2$ to +2$)$ around the earnings release. Specifically, we remove 23 restatements, of which 20 observations announce restatements exactly in the same day as the earnings release date. We remove these observations to mitigate concerns that any institutional trading or market reactions in response to the restatement information are confounded by disclosed earnings information which is not attributable to the restatement news. The final sample consists of 364 restatements on 334 unique firms.

\subsection{Variable Measurement}

The variables used in our empirical tests are defined in Appendix I Variable Definitions and discussed below.

\subsubsection{Institutional Holdings Variables}

Bushee (2001) classifies institutional investors into one of the three groups each year: transient, dedicated, and quasi-indexing institutions. This classification uses both factor analysis and cluster analysis based on each institutional investor's past investment behavior (for details, refer to Bushee, 1998, 2001; Bushee and Noe, 2000). Because the classification is highly stable over time, we follow Ke and Ramalingegowda (2005) to assign each institutional investor into the type that is the most frequent type for this institution over the classification period.

The institutional holdings variables are as follows for each firm-quarter: beginning level of aggregate institutional holdings of firm j's shares outstanding by a certain group of institutions ( INSTITUTION $N_{j, q-1}$ ), mean-adjusted change in aggregate institutional holdings of firm j's shares outstanding by a certain group of institutions $\left(\triangle A D J_{-}\right.$INSTITUTION $\left._{j, q}\right)$, and beginning weighted mean portfolio weight of firm $\mathrm{j}$ in the portfolio held by a certain group of institutions $\left(P W_{-}\right.$INSTITUTION $\left._{j, q-1}\right)$. INSTITUTION ${ }_{j, q-1}$ denotes either the holdings by total institutional investors (INST), or holdings by transient (TRA), dedicated (DED), or quasiindexing institutional investors $(Q I X) . \triangle A D J_{-} I N S T I T U T I O N_{j, q}$ is the mean-adjusted change in aggregate institutional holdings by a certain group of institutions (i.e., total, transient, dedicated, and quasi-indexing institutions, respectively) over the calendar quarter q for firm $j$. The adjustment is made by subtracting the average change in aggregate holdings by each group of institutions (i.e., total, transient, dedicated, and quasi-indexing institutions, respectively) across all firms on the CDA/Spectrum database over the same calendar quarter $q$, in order to control for time trends in the change in holdings by each group of institutions

\footnotetext{
${ }^{6} \mathrm{CDA} /$ Spectrum obtains their data from the SEC's 13-F form. SEC requires all institutions with greater than $\$ 100$ million of equity securities to report their holdings each calendar quarter on $13-\mathrm{F}$ form.
} 
(Abarbanell, Bushee, and Raedy, 2003). Following Ke and Petroni (2004) and Ke and Ramalingegowda (2005), PW_INSTITUTION ${ }_{j, q-1}$ measures the portfolio weight of firm $\mathrm{j}$ to the institutions' total holdings at the end of quarter q-1. PW_ INSTITUTION $N_{j, q-1}$ is calculated as $M V_{\text {institution, }, q-1} / M V_{\text {institution,all, } q-1}$, where $M V_{\text {institution, }, q-1}$ is the market value of firm $j$ held by a certain group of institutions (i.e., total, transient, dedicated, and quasi-indexing institutions, respectively) at the end of quarter q-1, and $M V_{\text {institution, all, } q-1}$ is the market value of all firms held by the same institutions (i.e., total, transient, dedicated, and quasi-indexing institutions, respectively) at the end of quarter q-1.

\subsubsection{Returns and Other Control Variables}

We measure cumulative market-adjusted abnormal returns using an equally weighted index over various windows surrounding the restatement announcement date. We measure 90-day (day -92 to day -3) cumulative abnormal returns prior to the restatement announcement to capture the pre-announcement market reaction. We measure 5-day (day -2 to day +2 ) cumulative abnormal returns around the restatement announcement to capture the immediate market reaction to restatements.

Earlier research shows that institutional holdings are systematically related to firm size and book-to-market (Gompers and Metrick, 2001), seasonally adjusted changes in earnings (Bartov, Radhakrishnan, and Krinsky, 2000; Ke and Ramaligegowda, 2005), and return momentum (Badrindath and Wahal, 2002). Accordingly, we include these variables to isolate the potential impacts of these firm-specific characteristics on institutional trading behavior around restatement announcements. We measure firm size $\left(L N S I Z E_{q-1}\right)$ by the natural $\log$ of book value of total assets (DATA44) at the beginning of the observation fiscal quarter q. Book-to-market $\left(B M_{q-1}\right)$ is the ratio of common book equity to total market capitalization at the beginning of the observation fiscal quarter (DATA59/(DATA14*DATA61)). Pricedeflated seasonal earnings change $\left(U E_{q-1}\right)$ prior to the observation fiscal quarter is the difference in earnings per share before extraordinary items (DATA9) from fiscal quarter q-5 to q-1, scaled by the ending price at fiscal quarter q-2. We include two momentum controls, which we compute using the buy-and-hold daily returns for one calendar quarter $\left(\right.$ RETQ1 $\left.1_{q}\right)$ and for two through four calendar quarters $\left(R E T Q 24_{q}\right)$ prior to the observation calendar quarter q, to capture short and longer term return momentum.

\subsection{Descriptive Statistics}

Table 1, panel A provides the descriptive statistics for 364 restatement announcement quarters. Among the different types of institutions, quasi-indexers have the largest average holdings, consistent with the popularity of index funds (Ke and Ramalingegowda, 2005). All types of institutions show a negative change in institutional holdings in the quarter of the restatement, although transient institutions exhibit the largest decrease in holdings, consistent with the short-term focus of transient institutions. Consistent with the earlier studies, the sample firm size ( $S I Z E$ ) is highly skewed. The mean of total assets at the beginning of the restating quarter is $\$ 4,460.46$ million, while the median is $\$ 363.28$ million. The mean of book-to-market ratio ( $B M)$ at the beginning of the restating quarter is 0.58 . The mean pricedeflated quarterly change in EPS before extraordinary items prior to the restating quarter $(U E)$ is -0.03 . Table 1 , panel B reports the descriptive statistics for 113,658 COMPUSTAT firm-quarters. 113,658 COMPUSTAT firm-quarters are obtained by excluding the restating 
firms from the COMPUTAT population for the period 1997- 2002. Comparing with 364 restatement firms, the COMPUSTAT firms have lower level of ownership by total, transient, dedicated, and quasi-indexing institutions. Moreover, the COMPUSTAT firms on average have a positive change in total, transient, dedicated, and quasi-indexing institutional ownership over a quarter, whereas 364 restatement firms have significantly negative change in total, transient, and quasi-indexing institutional ownership, consistent with the notion that restatement events trigger reduction in institutional holdings when restatements are announced. With regard to firm-specific controls, the COMPUSTAT firms are smaller and more profitable than the 364 restatement firms, consistent with prior studies (Myers et al., 2003). Taken together, our restatement firms have different firm characteristics than the COMPUSTAT population, which provides further support to our model specifications of using the restating firm as its own control rather than using a cross-sectional research design. ${ }^{7}$

Table 1. Descriptive Statistics

\begin{tabular}{|c|c|c|c|c|c|}
\hline & Mean & Std. & Q1 & Median & Q3 \\
\hline \multicolumn{6}{|c|}{ Panel A: Restatements } \\
\hline INST $(\%)_{\mathrm{q}-1}$ & $41.46^{*}$ & 26.27 & 18.54 & 40.60 & 63.76 \\
\hline$\Delta$ ADJ_INST $(\%)_{\mathrm{q}}$ & $-1.70^{*}$ & 8.20 & -3.45 & -0.37 & 1.70 \\
\hline PW_INST $(\%)_{\mathrm{q}-1}$ & $0.03 *$ & 0.07 & 0.00 & 0.00 & 0.02 \\
\hline TRA $(\%)_{q-1}$ & $11.62 *$ & 10.85 & 2.27 & 8.85 & 18.45 \\
\hline$\Delta$ ADJ_TRA $(\%)_{\mathrm{q}}$ & $-1.17 *$ & 5.17 & -2.08 & -0.17 & 0.95 \\
\hline PW_TRA $(\%)_{\mathrm{q}-1}$ & $0.05^{*}$ & 0.09 & 0.00 & 0.02 & 0.05 \\
\hline $\operatorname{DED}(\%)_{\mathrm{q}-1}$ & $11.53^{*}$ & 9.72 & 4.27 & 8.83 & 16.45 \\
\hline$\Delta$ ADJ_DED $(\%)_{q}$ & -0.25 & 3.51 & -1.06 & -0.08 & 0.88 \\
\hline PW_DED $(\%)_{\mathrm{q}-1}$ & $0.05^{*}$ & 0.18 & 0.00 & 0.01 & 0.02 \\
\hline$\overline{Q I X}(\%)_{\mathrm{q}-1}$ & $19.26^{*}$ & 13.79 & 5.48 & 19.33 & 30.92 \\
\hline$\Delta$ ADJ_QIX $(\%)_{\mathrm{q}}$ & $-0.54 *$ & 3.94 & -1.56 & -0.12 & 0.97 \\
\hline PW_QIX $(\%)_{\mathrm{q}-1}$ & $0.03 *$ & 0.07 & 0.00 & 0.00 & 0.02 \\
\hline $\operatorname{SIZE}_{q-1}$ & $4460.46^{*}$ & 27656.77 & 79.81 & 363.28 & 1723.60 \\
\hline LNSIZE $_{\mathrm{q}-1}$ & $6.00^{*}$ & 2.10 & 4.38 & 5.90 & 7.45 \\
\hline $\mathrm{BM}_{\mathrm{q}-1}$ & $0.58^{*}$ & 0.83 & 0.21 & 0.41 & 0.78 \\
\hline $\mathrm{UE}_{\mathrm{q}-1}$ & $-0.03 *$ & 0.24 & -0.03 & -0.01 & 0.00 \\
\hline RETQ1 $_{q}$ & 0.01 & 0.40 & -0.24 & -0.01 & 0.19 \\
\hline RETQ24 $_{q}$ & $0.10^{*}$ & 0.74 & -0.35 & -0.01 & 0.29 \\
\hline \multicolumn{6}{|c|}{$\begin{array}{l}\text { Panel B: } \\
\text { COMPUSTAT Firms }\end{array}$} \\
\hline $\operatorname{INST}(\%)_{\mathrm{q}-1}$ & $33.06^{*}$ & 26.00 & 9.63 & 27.91 & 53.67 \\
\hline$\Delta$ ADJ_INST $(\%)_{q}$ & $0.11 *$ & 6.44 & -1.77 & -0.07 & 1.94 \\
\hline PW_INST $(\%)_{\mathrm{q}-1}$ & $0.02 *$ & 0.17 & 0.00 & 0.00 & 0.01 \\
\hline $\operatorname{TRA}(\%)_{\mathrm{q}-1}$ & $9.85^{*}$ & 10.53 & 1.56 & 6.49 & 14.79 \\
\hline$\Delta$ ADJ_TRA $(\%)_{q}$ & $0.04 *$ & 4.17 & $\begin{array}{l}-0.94 \\
\end{array}$ & -0.06 & 1.01 \\
\hline PW_TRA $(\%)_{\mathrm{q}-1}$ & $0.05^{*}$ & 0.42 & 0.00 & 0.01 & 0.04 \\
\hline $\operatorname{DED}(\%)_{\mathrm{q}-1}$ & $9.52 *$ & 9.02 & 2.82 & 7.12 & 13.79 \\
\hline
\end{tabular}

\footnotetext{
${ }^{7}$ In untabulated analysis, we also examine how Tobin $Q$ affects our findings (see Appendix I on the measurement of Tobin Q). First, we compare the Tobin Q between our restatement firms and the COMPUSTAT population. The mean of Tobin $\mathrm{Q}$ for the restatement firms is 2.26 , while that for the COMPUSTAT population is 2.14 , with the mean difference not significant at the $1 \%$ level. Further, we repeat the analyses in table 3, 4, and 5 by adding Tobin Q in equation (1), (2), and (3). Our results remain robust. Since research that examines change in institutional ownership does not typically include Tobin Q as an explanatory variable (see, for example, Bushee and Noe, 2000; Ke and Ramalingegowda, 2005), we do not include Tobin Q in the tables.
} 


\section{Macrothink}

Asian Journal of Finance \& Accounting

ISSN 1946-052X

2009, Vol. 1, No. 2: E4

\begin{tabular}{|l|l|l|l|l|l|}
\hline$\Delta$ ADJ_DED $(\%)_{q}$ & $0.03^{*}$ & 3.25 & -0.80 & -0.04 & 0.92 \\
\hline PW_DED $(\%)_{q-1}$ & $0.05^{*}$ & 0.49 & 0.00 & 0.00 & 0.02 \\
\hline QIX $(\%)_{q-1}$ & $15.99^{*}$ & 14.16 & 3.33 & 12.30 & 26.27 \\
\hline$\Delta$ ADJ_QIX $(\%)_{q}$ & $0.02^{*}$ & 3.62 & -0.87 & -0.03 & 0.98 \\
\hline PW_QIX $(\%)_{q-1}$ & $0.02^{*}$ & 0.11 & 0.00 & 0.00 & 0.01 \\
\hline SIZE $_{q-1}$ & $3440.35^{*}$ & 26216.14 & 61.06 & 238.46 & 932.48 \\
\hline LNSIZE $_{q-1}$ & $5.56^{*}$ & 2.04 & 4.11 & 5.47 & 6.84 \\
\hline BM $_{q-1}$ & $0.59^{*}$ & 6.53 & 0.29 & 0.53 & 0.87 \\
\hline UE $_{q-1}$ & 0.03 & 6.06 & -0.01 & 0.00 & 0.01 \\
\hline RETQ1 & $0.03^{*}$ & 0.38 & -0.15 & 0.00 & 0.16 \\
\hline RETQ24 & $0.11^{*}$ & 0.78 & -0.24 & 0.02 & 0.30 \\
\hline
\end{tabular}

Note. Panel A provides descriptive statistics for the sample of 364 restatement announcement quarters from 1997 to 2002. Panel B provides descriptive statistics for 113,658 COMPUSTAT firm-quarters from 1997 to 2002, obtained by excluding the restating firms from the COMPUSTAT population for the period 1997- 2002. See Appendix I for variable definitions. * denotes two-tailed significance at the $5 \%$ level for the mean of the variable of interest.

Table 2 presents correlations for the sample of 3,276 firm-quarters to test Hypothesis 1 (i.e., 364 restatements*9 quarters with each restating firm centered on the restatement announcement quarter). The correlations show that the mean-adjusted change in total institutional holdings for each firm-quarter $\left(\triangle A D J_{-} I N S T_{q}\right)$ is significantly negatively correlated with the beginning level of total institutional holdings ( $I N S T_{q-1}$ ), suggesting that it is important to include the level of institutional holdings as an explanatory variable in any specification where the change in institutional ownership is the dependent variable. Moreover, the change in total institutional holdings for each firm-quarter $\left(\triangle A D J_{-} I N S T_{q}\right)$ is significantly positively correlated with the stock returns over the most recent quarters $\left(R E T Q 1_{q}\right.$ and $\left.R E T Q 24_{q}\right)$, consistent with momentum trading of institutional investors. 


\section{Macrothink}

Table 2. Correlations among Variables

\begin{tabular}{|c|c|c|c|c|c|c|c|c|}
\hline & INST $\%_{q-1}$ & $\Delta$ ADJ_INST $\%_{q}$ & PW_INST\% $\%_{\mathrm{q}-1}$ & LNSIZE $_{\mathrm{q}-1}$ & $\mathrm{BM}_{\mathrm{q}-1}$ & $\mathrm{UE}_{\mathrm{q}-1}$. & RETQ1 $_{q}$ & RETQ24 $_{q}$ \\
\hline INST $\%_{\mathrm{q}-1}$ & & -0.091 & 0.300 & 0.559 & 0.028 & -0.015 & 0.064 & 0.142 \\
\hline$\Delta$ ADJ_INST $\%_{\mathrm{q}}$ & -0.026 & & 0.003 & 0.023 & -0.016 & 0.004 & 0.144 & 0.054 \\
\hline PW_INST\% $\%_{\mathrm{q}-1}$ & 0.752 & 0.081 & & 0.503 & -0.027 & -0.004 & 0.066 & 0.097 \\
\hline LNSIZE $_{\mathrm{q}-1}$ & 0.592 & 0.055 & 0.754 & & 0.023 & 0.002 & -0.005 & -0.001 \\
\hline $\mathrm{BM}_{\mathrm{q}-1}$ & -0.111 & -0.080 & -0.352 & 0.012 & & 0.138 & -0.046 & 0.011 \\
\hline $\mathrm{UE}_{\mathrm{q}-1}$ & 0.042 & 0.093 & 0.080 & -0.002 & -0.119 & & 0.025 & 0.000 \\
\hline RETQ1 $_{\mathrm{q}}$ & 0.095 & 0.154 & 0.209 & 0.064 & -0.210 & 0.170 & & 0.058 \\
\hline RETQ24 $_{q}$ & 0.235 & 0.076 & 0.347 & 0.124 & -0.317 & 0.193 & 0.075 & \\
\hline
\end{tabular}

Note. This table provides the correlation between each of the variables used in our empirical tests. The correlations are computed using 3,276 firm-quarters (=364 restatements $* 9$ quarters with each restating firm centered on the restatement announcement quarter). The 364 restatements are announced from the period 1997 to 2002. Pearson (spearman) correlations are above (below) the diagonal. Bold figures indicate two-tailed significance at the 1\% level. See Appendix I for variable definitions. 


\section{Research Design and Empirical Results}

\subsection{Institutional Investors' Trading Patterns Surrounding Announcements of Restatements}

We begin by examining the changes in institutional holdings without including any additional controls. The pattern of mean-adjusted changes in holdings over time by total and by different types of institutional investors is depicted in Figure 1. Panel A shows that total institutions in general sell intensively in the restating quarter (mean-adjusted change in institutional holdings is $-1.70 \%$ of the restating firm's shares outstanding), but there is no visual evidence of substantial selling in advance of the restatement (mean-adjusted change in institutional holdings is $-0.04 \%$ of the restating firm's shares outstanding). However, after partitioning institutional investors into transient, dedicated, and quasi-indexing institutions in Panel B, we see preliminary evidence that selling by transient institutions begins one quarter before the restating quarter, with a reduction in holdings of $-0.29 \%$ of the restating firm's shares outstanding, which represents an decrease of $2.4 \%$ of the restating firm's aggregate transient institutional holdings (=$0.29 \% / 11.84 \%, 11.84 \%$ is the mean of the restating firm's beginning aggregate transient institutional holdings). We also see a decrease in holdings by the quasi-indexers of $-0.32 \%$ of the restating firm's shares outstanding, which represents a decrease of $1.6 \%$ of the restating firm's aggregate quasi-indexing institutional holdings $(=-0.32 \% / 19.64 \%, 19.64 \%$ is the mean of the restating firm's beginning aggregate quasi-indexing institutional holdings). Interestingly, dedicated investors appear to increase their holdings by $0.46 \%$ of the restating firm's shares outstanding in the quarter prior to the restatement, and this increase in holdings corresponds to $4.3 \%$ of the restating firm's aggregate dedicated institutional holdings $(=0.46 \% / 10.78 \%, 10.78 \%$ is the mean of the restating firms' beginning aggregate dedicated institutional holdings). One possibility is that dedicated investors are committed to firms for the long term and, conditional on not knowing whether a firm will restate, the decline in share price of restating companies in the quarter prior to a restatement makes it a relatively attractive time to purchase shares. ${ }^{8}$ This result suggests that it is unlikely that management has privately communicated the possibility of future bad news, because all types of institutions reduce their holdings after the restatement is announced. Overall, the pattern of the mean-adjusted changes in holdings suggest that all types of institutional investors sell shares in the quarter of the restatement, but it is primarily the transient institutions that appear to sell more holdings one quarter in advance.

\footnotetext{
${ }^{8}$ Currently, our tests cannot say whether transient or dedicated investors have a 'better' investment strategy, because we do not have a sample of firms that have the characteristics of restating firms that never end up having a restatement. Therefore, our paper is not intended to say that transient institutions are more sophisticated or follow a better investment strategy by reducing their holdings prior to the restatement, because our sample is composed of only ex-post restatement firms. It could well be that across all firms, buying firms with the characteristics of a restating firm in the quarter prior to the restatement is a better investment strategy than selling these firms, depending on the number of firms that share these characteristics and the difference in stock returns if a firm restates or not. We leave this question to future research.
} 


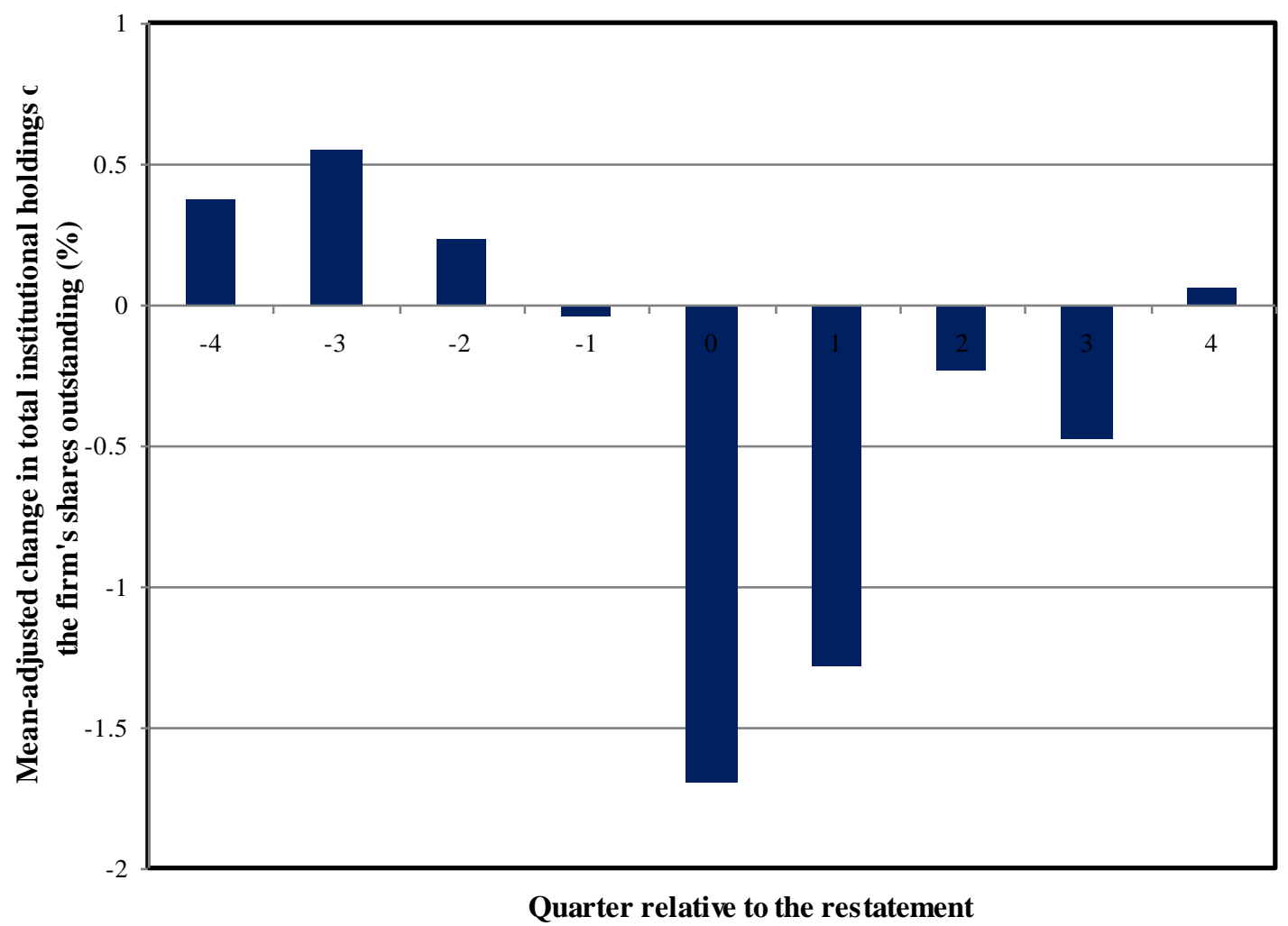

Panel A. Total Institutional Holdings

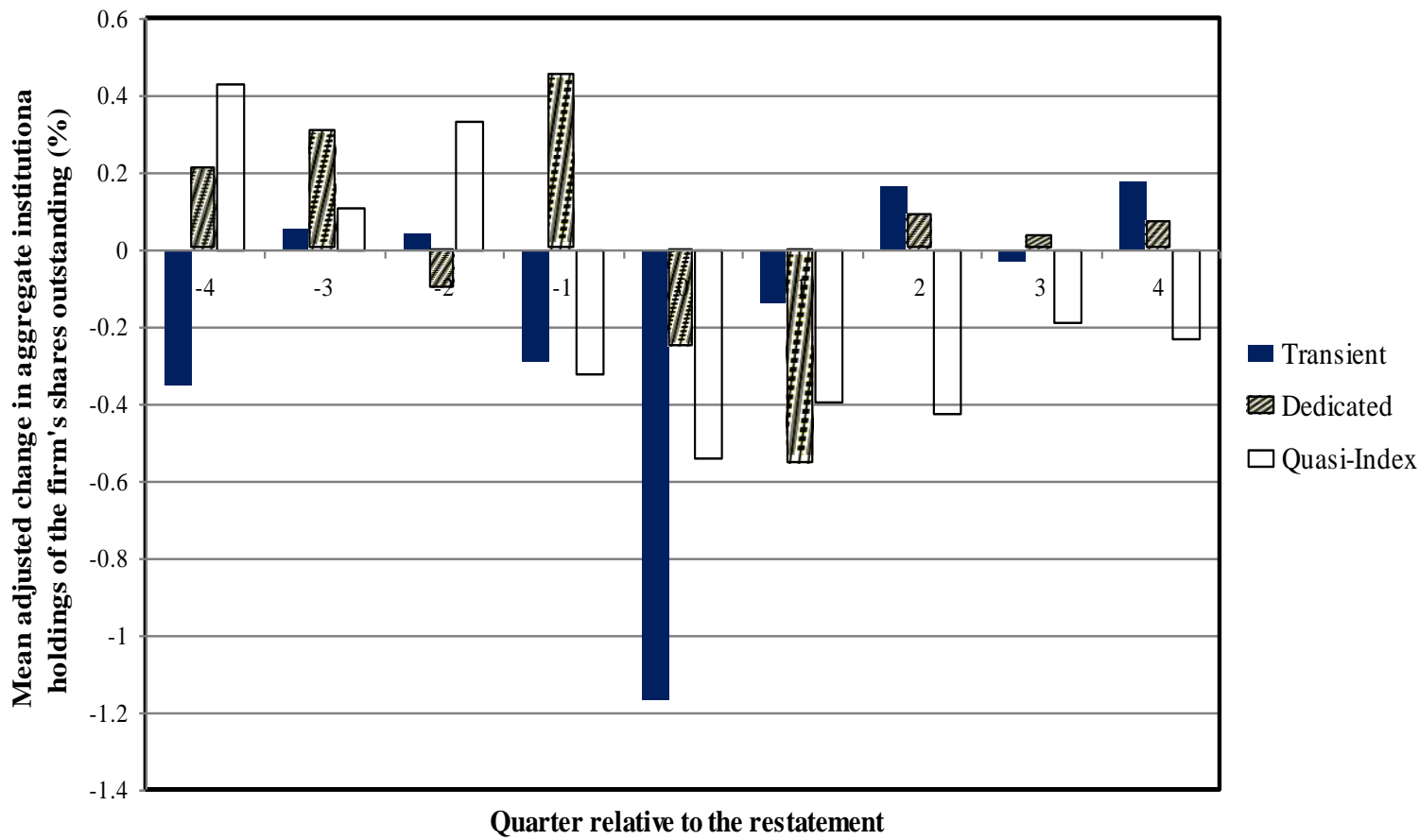

Panel B. By Institutional Type 
Figure 1. Mean-adjusted Change in Institutional Holdings of the Restating Firms' Shares Outstanding Relative to the Quarter of an Accounting Restatement

Because there are additional factors that may be associated with changes in institutional holdings, our formal examination of the first research question uses a regression design that allows us to include a number of other determinants of institutional trading. To establish the statistical significance of the changes in holdings in the quarters prior to the restatement, we use the firm as its own control. In particular, we acquire data for each restating firm for 9 quarters, centered on the restatement announcement quarter, and measure the changes in institutional holdings in the quarters of interest relative to average changes in holdings. We choose 9 quarters centered on the restatement announcement quarter (i.e., -4 to 4 quarters around the restatement announcement quarter) following prior work (e.g., Abarbanell, Bushee, and Raedy, 2003). We use this approach instead of a matched sample or cross-sectional design for two main reasons. First, using the firm as its own control and measuring the changes in institutional holdings relative to the restatement date allows us to hold constant other firm characteristics that are more likely to vary significantly in a cross-sectional research design than over the 9-quarter event period that we examine. Second, the use of this within-subjects research design provides a more powerful test because the cross-sectional differences between firms are not included in the error variance. This is particularly important when observations are limited as is the case with the restatement database.

Therefore, we carry out the regression for total institutional ownership, as well as for each group of institutions classified by investment style using the following regression model:

$$
\begin{aligned}
& \triangle A D J_{-} \text {INSTITUTION } \%_{j, q}=\beta_{0} \text { RESTATE }+\beta_{1} \text { PRERESTATE } 1+\beta_{2} \text { PRERESTATE } 2
\end{aligned}
$$

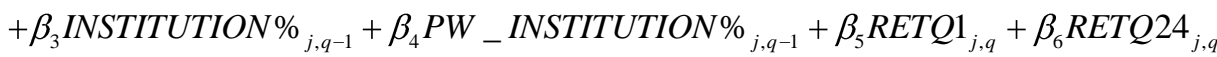

$$
\begin{aligned}
& +\beta_{7} \text { LNSIZE }_{j, q-1}+\beta_{8} B M_{j, q-1}+\beta_{9} U E_{j, q-1}+\text { YearDummies }+ \text { IndustryDummies }
\end{aligned}
$$

where $\triangle A D J_{-}$INSTITUTIO $N_{j, q}$ is the mean-adjusted change over quarter $\mathrm{q}$ in aggregate institutional holdings by INSTITUTION for firm $\mathrm{j}$, where INSTITUTION denotes holdings by all institutions (INST) or holdings by transient (TRA), dedicated ( $D E D$ ), or quasi-indexing institutions ( $Q I X)$ for each firm. RESTATE is equal to one if the firm announced a restatement in that quarter and equal to zero otherwise. PRERESTATE1 (PRERESTATE2) is equal to one if the institutional ownership measurement quarter is one (two) quarter(s) prior to the restating quarter and equal to zero otherwise. The beginning level of institutional holdings (в INSTITUTION $\left._{j, q-1}\right)$ and the beginning portfolio weight of firm $\mathrm{j}\left(P_{-}\right.$INSTITUTION $\left._{j, q-1}\right)$ are included in order to control for the effects of level and concentration of institutional holdings on changes in institutional ownership (Ke and Petroni, 2004; Ke and Ramalingegowda, 2005). ${ }^{9}$

\footnotetext{
${ }^{9}$ We attempt to control for potential endogeneity in several ways. First, our explanatory variables in the models (equation (1) and (2)) are measured with a lag with the dependent variables (i.e., change in different institutional ownership). Such model specifications mitigate the potential endogeneity that both change in institutional ownership and our explanatory variables are jointly and contemporaneously determined by certain omitted firm features. Next, we use the restating firm as its control and examine each restating firm for 9 quarters, centered on the restatement announcement quarter. Using the firm as its own control and measuring the change in institutional holdings relative to the restatement date allows us to hold constant other firm characteristics that more likely to vary significantly in a cross-sectional research design than over the 9-quarter event period that we examine. Accordingly, our time-series 
We posit that transient institutional investors begin to sell restating firms prior to the quarter of the restatement announcement. This implies a significant negative coefficient on PRERESTATE1 $\left(\beta \mathrm{B}_{1 \mathrm{~B}}<0\right)$ for holdings by transient institutions. We also examine institutional trading two quarters prior to the restatement quarter using PRERESTATE2, to determine whether there is evidence of informed trading even further in advance. We expect the coefficient on $P W_{-}$INSTITUTIO $N_{j, q-1}$ to be negative, as institutions are more likely to unwind their positions if their beginning holdings are more concentrated on a given firm (Ke and Petroni, 2004). The coefficients on the momentum control variables, $R E T Q 1_{j, q}$ and $R E T Q 24_{j, q}$, are expected to be positive, as institutions have been shown to trade on return momentum. Firm size $\left(L N S I Z E_{j, q-1}\right)$, book-to-market ratio $\left(B M_{j, q-1}\right)$, and price-deflated seasonal earnings change $\left(U E_{j, q-1}\right)$ are included to control for the effects of firm-specific characteristics on the cross-sectional differences in institutional trading behaviors. We control for outliers by eliminating observations if the absolute value of studentized residuals or DFFITS influence statistics are greater than or equal to 1.9 .

Table 3 presents the results of estimating Equation (1) regarding institutional trading patterns surrounding restatement announcements, controlling for the firm-specific determinants of institutional trading behavior. Table 3 shows that institutional investors as a whole do not appear to anticipate the impending restatement (coefficient on PRERESATE1 =-0.077, p-value=0.76), although they significantly reduce their holdings during the restating quarter (coefficient on RESTATE $=-1.053$, p-value=0.00). Table 3 also presents the estimation of Equation (1) for transient (TRA), dedicated ( $D E D$ ) and quasi-indexing institutions ( $Q I X)$, respectively. As predicted, the coefficient on PRERESTATE1 is significantly negative for transient institutions (coefficient $=-0.391$, $\mathrm{p}$-value $=0.02$ ), indicating that transient institutions predict accounting restatements and start selling one quarter in advance to avoid the negative announcement returns associated with the restatement announcements. This finding supports the notion that institutional investors are able to anticipate accounting restatements at least one quarter ahead. Nevertheless, it is still the case that the greatest amount of institutional selling by the transient institutions occurs during the restating quarter, as evidenced by a more negative coefficient on RESTATE (coefficient=-0.776, p-value=0.00) relative to the coefficient on PRERESATE1 . As expected, the coefficient on $P W_{-} T R A_{j, q-1}$ is significantly negative (coefficient=-1.640, pvalue $=0.01$, consistent with the notion that the higher the beginning portfolio concentration, the more selling by transient institutions in the current observation quarter. In contrast, there is no evidence that other groups of institutions (i.e., dedicated and quasi-indexing) sell the restating firm in advance of the restatement. In particular, dedicated institutions appear to significantly increase holdings one quarter prior to the restatement announcement quarter (coefficient $=0.251$, p-value $=0.04$ ), consistent with the institutional investors' trading patterns surrounding announcements of restatements as illustrated in Figure 1. Again, this evidence suggests that it is

research design alleviates the potential endogeneity that change in institutional holdings may be caused by certain omitted firm characteristics correlated with restatement events. Lastly, we control for potential endogeneity by choosing the determinants of the change in institutional holdings based on the extant literature (e.g., Ke and Ramaligegowda, 2005), in order to include factors that likely affect change in institutional holdings. In doing so, we reduce the likelihood of omitted correlated variable problems in this study. 
unlikely that management has privately communicated the possibility of future bad news to institutional investors. Quasi-indexers do not appear to trade significantly one quarter ahead of the restatement quarter. The lack of selling by dedicated and quasi-indexing institutions underscores the importance of focusing on the appropriate set of institutions when examining short term information-based trading.

Table 3. Institutional Trading around Announcements of Accounting Restatements

\begin{tabular}{|c|c|c|c|c|}
\hline & \multicolumn{4}{|c|}{ Dependent variable } \\
\hline $\begin{array}{l}\text { Independent } \\
\text { variables }\end{array}$ & $\triangle \mathrm{ADJ} \_I N S T \%_{\mathrm{q}}$ & $\triangle \mathrm{ADJ} \_\mathrm{TRA} \%_{\mathrm{q}}$ & $\triangle \mathrm{ADJ} \_D E D \%_{\mathrm{q}}$ & $\Delta$ ADJ_QIX\% $\%_{\mathrm{g}}$ \\
\hline INTERCEPT & $\begin{array}{l}-0.946 \\
(-1.30)\end{array}$ & $\begin{array}{l}0.070 \\
(0.14)\end{array}$ & $\begin{array}{l}0.392 \\
(1.07)\end{array}$ & $\begin{array}{l}-0.571 \\
(-1.40)\end{array}$ \\
\hline RESTATE & $\begin{array}{l}-1.053^{* * *} \\
(-4.21)\end{array}$ & $\begin{array}{l}-0.776^{* * * *} \\
(-4.54)\end{array}$ & $\begin{array}{l}-0.064 \\
(-0.53)\end{array}$ & $\begin{array}{l}-0.350 * * \\
(-2.52)\end{array}$ \\
\hline PRERESTATE1 & $\begin{array}{l}-0.077 \\
(-0.30)\end{array}$ & $\begin{array}{l}-0.391 * * \\
(-2.27)\end{array}$ & $\begin{array}{l}0.251^{* *} \\
(2.04)\end{array}$ & $\begin{array}{l}-0.234 \\
(-1.64)\end{array}$ \\
\hline PRERESTATE2 & $\begin{array}{l}0.113 \\
(0.44)\end{array}$ & $\begin{array}{l}-0.040 \\
(-0.23)\end{array}$ & $\begin{array}{l}0.049 \\
(0.40)\end{array}$ & $\begin{array}{l}0.202 \\
(1.40)\end{array}$ \\
\hline INSTITUTION\% ${ }_{\mathrm{q}-1}{ }^{a}$ & $\begin{array}{l}-0.022 * * * \\
(-5.71)\end{array}$ & $\begin{array}{l}-0.064 * * * \\
(-10.79)\end{array}$ & $\begin{array}{l}-0.033 \text { *** } \\
(-7.72)\end{array}$ & $\begin{array}{l}-0.028 * * * \\
(-6.50)\end{array}$ \\
\hline PW_INSTITUTION\% ${ }_{\mathrm{q}-1}$ & $\begin{array}{l}-3.316^{* * * *} \\
(-2.78)\end{array}$ & $\begin{array}{l}-1.640 \text { *** } \\
(-2.61)\end{array}$ & $\begin{array}{l}-0.128 \\
(-0.54)\end{array}$ & $\begin{array}{l}-0.818 \\
(-1.27)\end{array}$ \\
\hline RETQ1 $1_{\mathrm{q}}$ & $\begin{array}{l}1.977 * * * \\
(9.48)\end{array}$ & $\begin{array}{l}1.252^{* * *} \\
(8.79)\end{array}$ & $\begin{array}{l}0.115 \\
(1.12)\end{array}$ & $\begin{array}{l}0.741 \text { *** } \\
(6.41)\end{array}$ \\
\hline RETQ24 $_{\mathrm{q}}$ & $\begin{array}{l}0.564 * * * \\
(5.09)\end{array}$ & $\begin{array}{l}0.080 \\
(1.02)\end{array}$ & $\begin{array}{l}0.052 \\
(0.99)\end{array}$ & $\begin{array}{l}0.262 * * * \\
(4.35)\end{array}$ \\
\hline LNSIZE $_{\mathrm{q}-1}$ & $\begin{array}{l}0.343 \text { *** } \\
(5.88)\end{array}$ & $\begin{array}{l}0.182 * * * \\
(5.46)\end{array}$ & $\begin{array}{l}0.032 \\
(1.51)\end{array}$ & $\begin{array}{l}0.201 * * * \\
(5.98)\end{array}$ \\
\hline $\mathrm{BM}_{\mathrm{q}-1}$ & $\begin{array}{l}-0.153^{*} \\
(-1.89)\end{array}$ & $\begin{array}{l}-0.201 * * * \\
(-3.04)\end{array}$ & $\begin{array}{l}0.018 \\
(0.42)\end{array}$ & $\begin{array}{l}-0.125^{* * *} \\
(-2.61)\end{array}$ \\
\hline $\mathrm{UE}_{\mathrm{q}-1}$ & $\begin{array}{l}-0.138 \\
(-0.49)\end{array}$ & $\begin{array}{l}0.025 \\
(0.10)\end{array}$ & $\begin{array}{l}0.002 \\
(0.07)\end{array}$ & $\begin{array}{l}0.262 \\
(1.52)\end{array}$ \\
\hline Year Fixed Effects & Included & Included & Included & Included \\
\hline Industry Fixed Effects & Included & Included & Included & Included \\
\hline Adjusted $\mathrm{R}^{2}$ & 0.063 & 0.085 & 0.024 & 0.044 \\
\hline
\end{tabular}

Note. This table presents the estimated Equation (1) to test whether institutional investors anticipate the restatement at least one quarter in advance. The sample consists of 3,276 firm-quarters $(=364$ restatements $* 9$ quarters with each restating firm centered on the restatement announcement quarter). The 364 restatements are announced from the period 1997 to 2002. See Appendix I for variable definitions. ${ }^{a}$ INSTITUTION denotes holdings by total institution (INST), holdings by transient (TRA), dedicated (DED), and quasi-indexing institutions (QIX) for each firm-quarter, depending on the column being examined. For brevity, YEAR and INDUSTRY variables are omitted from the table. Outliers in the regressions are deleted when the absolute value of studentized residuals or DFFITS influence statistics is greater than or equal to 1.9 . $* * * * *$, and $*$ denote two-tailed significance at the $0.01,0.05$ and 0.1 levels, respectively. t-statistics are presented in parentheses.

To learn more about the types of information that institutions might be using, we add variables that have been shown in the past to predict earnings manipulation. Beneish (1999) develops a 
model using the accounting factors to predict accounting enforcement actions by the SEC for violating GAAP. We include these factors in our model and estimate the following regression: ${ }^{10}$

$$
\begin{aligned}
& \triangle A D J_{2} \text { INSTITUTION } \%_{j, q}=\beta_{0} \text { RESTATE }+\beta_{1} \text { PRERESTATE } 1+\beta_{2} \text { PRERESTATE } 2
\end{aligned}
$$

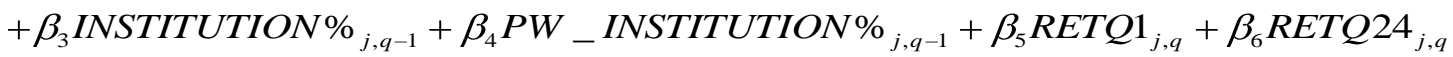

$$
\begin{aligned}
& +\beta_{7} L_{N S I Z E_{j, q-1}}+\beta_{8} B M_{j, q-1}+\beta_{9} U E_{j, q-1}+\beta_{10} D S R I_{j, q}+\beta_{11} G M I_{j, q}+\beta_{12} A Q I_{j, q}+\beta_{13} S G I_{j, q} \\
& +\beta_{14} D_{E P I_{j, q}}+\beta_{15} \text { TATA }_{j, q}+\text { YearDummies + IndustryDummies }
\end{aligned}
$$

where all the variables except the accounting factors are defined in Equation (1). The accounting factors are defined in Appendix I Variable Definitions and are discussed below. Days sales in receivables index $\left(D S R I_{q}\right)$, measures the number of days in accounts receivables this year relative to last year, potentially useful for detecting revenue recognition-based earnings management. Gross margin index $\left(G M I_{q}\right)$ measures the reduction in the gross-margin year over year, evidence of potential profit pressure. Asset quality index $\left(A Q I_{q}\right)$ measures the percentage of 'soft' assets that are potentially more malleable. Sales growth index $\left(S G I_{q}\right)$ measures sales growth, as high growth firms often face greater capital market pressures and may have greater incentive for earnings manipulation. Depreciation index $\left(D E P I_{q}\right)$ measures depreciation rates relative to total PPE for possible changes in depreciation policies, estimated useful lives, etc. Total accruals to total assets $\left(T A T A_{q}\right)$ is a catchall for any potential accrual based earnings management not captured by the other measures. Note that all factors are defined such that a higher number increases the likelihood of earnings manipulation. Some of these measures are intended to try to provide flags about possible manipulation, while others are simply incentive variables intended to capture firms with greater incentives to manage earnings. Because we use quarterly changes in institutional holdings, we define these 6 factors based on the trailing four quarters of data available to the institutions prior to the reported end of quarterly holdings. Since these variables are mainly based on year-to-year changes which introduces a potential problem when the denominator is small, we winsorize each variable at the $1 \%$ and $99 \%$ of its distribution following Beneish (1999).

Results of estimating Equation (2) are presented in Table 4 for each of the institutional types. Looking at the column related to transient institutional investors, of the six factors included in the model, two are significant in the predicted direction. $D S R I_{j, q}$, which measures an increase in the accounts receivable balance relative to sales, is negatively associated with change in transient institutional holdings (coefficient $=-0.183$, $\mathrm{p}$-value $=0.09)$. Total accruals $\left(T_{A T A_{j, q}}\right)$ is also negatively associated with changes in transient institutional ownership (coefficient $=-1.110$, p-value $=0.00$ ). None of the other factors are associated with changes in institutional holdings. Overall, the results of including the earnings manipulation variables shows that institutions are more likely to reduce their holdings when there is an increase in the days sales in receivables or high accruals. However, PRERESTATE1 continues to be significantly negative one quarter in advance (coefficient $=-0.401$, $\mathrm{p}$-value $=0.04$ ), suggesting that institutional investors use other

\footnotetext{
${ }^{10}$ Beneish includes two additional measures in his model, leverage and SG\&A expense, neither of which is related to SEC enforcement actions. As a result, we do not include them in our regression.
} 
information in addition to these two factors when deciding to reduce their holdings before the restatement announcement. ${ }^{11}$

Table 4. Institutional Trading and Financial Statement Predictors of Restatements

\begin{tabular}{|c|c|c|c|c|}
\hline $\begin{array}{c}\text { Independent } \\
\text { variable }\end{array}$ & $\Delta$ ADJ_INST $\%_{\mathrm{q}}$ & $\Delta \mathrm{ADJ} \_\mathrm{TRA} \%_{\mathrm{q}}$ & $\triangle \mathrm{ADJ} \_\mathrm{DED} \%_{\mathrm{q}}$ & $\Delta$ ADJ_QIX $\%_{\mathrm{q}}$ \\
\hline INTERCEPT & $\begin{array}{l}-0.226 \\
(-0.25) \\
\end{array}$ & $\begin{array}{l}0.008 \\
(0.01) \\
\end{array}$ & $\begin{array}{l}0.989 * * \\
(2.08) \\
\end{array}$ & $\begin{array}{l}-0.140 \\
(-0.27)\end{array}$ \\
\hline RESTATE & $\begin{array}{l}-1.215 * * * \\
(-4.45)\end{array}$ & $\begin{array}{l}-0.877 * * * \\
(-4.57)\end{array}$ & $\begin{array}{l}-0.141 \\
(-1.06)\end{array}$ & $\begin{array}{l}-0.404 * * * \\
(-2.66)\end{array}$ \\
\hline PRERESTATE1 & $\begin{array}{l}-0.023 \\
(-0.08)\end{array}$ & $\begin{array}{l}-0.401 * * \\
(-2.07)\end{array}$ & $\begin{array}{l}0.228^{*} \\
(1.70)\end{array}$ & $\begin{array}{l}-0.115 \\
(-0.74)\end{array}$ \\
\hline PRERESTATE2 & $\begin{array}{l}0.140 \\
(0.49)\end{array}$ & $\begin{array}{l}-0.062 \\
(-0.32)\end{array}$ & $\begin{array}{l}-0.000 \\
(0.00)\end{array}$ & $\begin{array}{l}0.176 \\
(1.11)\end{array}$ \\
\hline INSTITUTION\% ${ }_{\mathrm{q}-1}{ }^{\mathrm{a}}$ & $\begin{array}{l}-0.025 * * * \\
(-5.60)\end{array}$ & $\begin{array}{l}-0.068 * * * \\
(-10.21)\end{array}$ & $\begin{array}{l}-0.040 * * * \\
(-7.89)\end{array}$ & $\begin{array}{l}-0.030 * * * \\
(-6.20)\end{array}$ \\
\hline PW_INSTITUTION\% ${ }_{\mathrm{q}-1}$ & $\begin{array}{l}-3.332 * * * \\
(-2.69)\end{array}$ & $\begin{array}{l}-2.106 * * * \\
(-3.00)\end{array}$ & $\begin{array}{l}-0.062 \\
(-0.25)\end{array}$ & $\begin{array}{l}-0.781 \\
(-1.16)\end{array}$ \\
\hline RETQ1 $_{\mathrm{q}}$ & $\begin{array}{l}1.991 * * * \\
(9.04)\end{array}$ & $\begin{array}{l}1.258 * * * \\
(8.17)\end{array}$ & $\begin{array}{l}0.204 * \\
(1.87)\end{array}$ & $\begin{array}{l}0.742 * * * \\
(6.06)\end{array}$ \\
\hline RETQ24 $_{\mathrm{q}}$ & $\begin{array}{l}0.659 * * * \\
(5.32)\end{array}$ & $\begin{array}{l}0.205^{* *} \\
(2.27)\end{array}$ & $\begin{array}{l}0.040 \\
(0.68) \\
\end{array}$ & $\begin{array}{l}0.277 * * * \\
(4.12)\end{array}$ \\
\hline LNSIZE $_{\mathrm{q}-1}$ & $\begin{array}{l}0.368 * * * \\
(5.64)\end{array}$ & $\begin{array}{l}0.248 * * * \\
(6.46)\end{array}$ & $\begin{array}{l}0.024 \\
(1.02) \\
\end{array}$ & $\begin{array}{l}0.213 * * * \\
(5.66)\end{array}$ \\
\hline $\mathrm{BM}_{\mathrm{q}-1}$ & $\begin{array}{l}-0.143^{*} \\
(-1.68)\end{array}$ & $\begin{array}{l}-0.169 * * \\
(-2.39)\end{array}$ & $\begin{array}{l}0.013 \\
(0.29)\end{array}$ & $\begin{array}{l}-0.136 * * * \\
(-2.70)\end{array}$ \\
\hline $\mathrm{UE}_{\mathrm{q}-1}$ & $\begin{array}{l}-0.153 \\
(-0.52)\end{array}$ & $\begin{array}{l}-0.122 \\
(-0.46)\end{array}$ & $\begin{array}{l}0.115 \\
(0.48)\end{array}$ & $\begin{array}{l}0.334 * \\
(1.85)\end{array}$ \\
\hline $\operatorname{DSRI}_{\mathrm{q}}$ & $\begin{array}{l}-0.589 * * * \\
(-3.95)\end{array}$ & $\begin{array}{l}-0.183^{*} \\
(-1.72)\end{array}$ & $\begin{array}{l}-0.247 * * * \\
(-3.48)\end{array}$ & $\begin{array}{l}-0.060 \\
(-0.72)\end{array}$ \\
\hline $\mathrm{GMI}_{\mathrm{q}}$ & $\begin{array}{l}-0.017 \\
(-0.19)\end{array}$ & $\begin{array}{l}0.027 \\
(0.39)\end{array}$ & $\begin{array}{l}-0.025 \\
(-0.55)\end{array}$ & $\begin{array}{l}-0.033 \\
(-0.65)\end{array}$ \\
\hline $\mathrm{AQI}_{\mathrm{q}}$ & $\begin{array}{l}0.026^{* * * *} \\
(3.19)\end{array}$ & $\begin{array}{l}0.008 \\
(1.42)\end{array}$ & $\begin{array}{l}0.001 \\
(0.34)\end{array}$ & $\begin{array}{l}0.001 \\
(0.20)\end{array}$ \\
\hline $\mathrm{SGI}_{\mathrm{q}}$ & $\begin{array}{l}0.073 \\
(0.98)\end{array}$ & $\begin{array}{l}0.030 \\
(0.58)\end{array}$ & $\begin{array}{l}0.021 \\
(0.57)\end{array}$ & $\begin{array}{l}0.051 \\
(1.24)\end{array}$ \\
\hline $\operatorname{DEPI}_{\mathrm{q}}$ & $\begin{array}{l}-0.442 \\
(-1.16)\end{array}$ & $\begin{array}{c}-0.078 \\
(-0.30)\end{array}$ & $\begin{array}{l}-0.245 \\
(-1.25)\end{array}$ & $\begin{array}{l}-0.397 * \\
(-1.86)\end{array}$ \\
\hline TATA $_{\mathrm{q}}$ & $\begin{array}{l}0.244 \\
(0.54) \\
\end{array}$ & $\begin{array}{l}1.110 * * * \\
(-3.53) \\
\end{array}$ & $\begin{array}{l}0.677 * * * \\
(2.94)\end{array}$ & $\begin{array}{l}0.115 \\
(0.46) \\
\end{array}$ \\
\hline Year Fixed Effects & Included & Included & Included & Included \\
\hline
\end{tabular}

${ }^{11}$ The correlations among the variables indicate that firm size $\left(\operatorname{LNSIZE}_{\mathrm{q}-1}\right)$ is positively correlated with total institutional holdings (INST\% ${ }_{\mathrm{q}-1}$ ) and the portfolio weight of the firm to institutions (PW_INST\% q-1). This is expected because larger firms usually attract more institutions and these institutions allocate higher weight of their holdings to larger firms (Gompers and Metrick, 2001; Wang, 2010). To assess the impact of multicollinearity, we compute the variance inflation factors (VIF) for each of the independent variables used in table 3 and 4 (except year and industry dummies). The measures indicate no substantial multicollinearity among the independent variables, with firm size to be the most collinear variable, having the highest VIF value of less than 3 (Kennedy, 2003). In order to ensure that the results in table 3 and 4 are not sensitive to the inclusion of firm size, we exclude firm size and repeat the analysis of table 3 and 4 . The untabulated results remain qualitatively similar. We choose to include firm size as an explanatory variable to be consistent with prior research (e.g., Ke and Petroni, 2004). 


\begin{tabular}{|l|l|l|l|l|}
\hline Industry Fixed Effects & Included & Included & Included & Included \\
\hline Adjusted R & 0.078 & 0.095 & 0.036 & 0.047 \\
\hline
\end{tabular}

Note. This table presents the estimated Equation (2) to test whether institutional investors anticipate the restatement at least one quarter in advance, adding controls of financial statement predictors of accounting restatements. The sample consists of 3,276 firm-quarters ( $=364$ restatements $* 9$ quarters with each restating firm centered on the restatement announcement quarter). The 364 restatements are announced from the period 1997 to 2002 . See the Appendix for variable definitions. ${ }^{a}$ INSTITUTION denotes holdings by all institution (INST); holdings by transient (TRA), dedicated (DED), and quasi-indexing institutions (QIX) for each firm-quarter, depending on the column being examined. For brevity, YEAR and INDUSTRY variables are omitted from the table. Outliers in the regressions are deleted when the absolute value of studentized residuals or DFFITS influence statistics is greater than or equal to 1.9 . ***, **, and * denote two-tailed significance at the $0.01,0.05$ and 0.1 levels, respectively. $\mathrm{t}-$ statistics are presented in parentheses.

Finally, in untabulated results we redo the analysis for Tables 3 and 4 using only the restatements that occur after the implementation of regulation Fair Disclosure (Reg FD). ${ }^{12}$ This reduces the number of restatements to 162 and reduces the sample to 1,458 firm-quarter observations $(=162$ restatements $* 9$ quarters with each restating firm centered on the restating quarter). The results are qualitatively the same, which provides additional evidence that information advantage via private communications with management are unlikely to be the source of informed trading by institutions with respect to a restatement, because after Reg FD managers are prohibited from privately sharing material information to select investors and therefore transient institutional investors are less likely to obtain private information disclosed from firm management after Reg FD. Note that institutional investors' information advantage is either from private information obtained from firm management and/or from superior analysis of public information. Consequently, after Reg FD if institutional investors continue to have information advantage, the information source of institutional investors is likely from their superior processing of public information because after Reg FD private information acquisition from firm management is less likely to be the information source of institutional investors with respect to a restatement.

\subsection{The Market Reaction to Restatements as a Function of Institutional Ownership}

Our second set of tests examines the stock price reaction as a function of levels of different institutional ownership. Based on the evidence in the previous section that transient institutional investors reduce their holdings in restating firms at least one quarter prior to the restatement, we next examine whether greater levels of transient institutional holdings affect the price formation process, such that greater transient institutional ownership accelerates the impounding of restatement related information into stock price in the pre-announcement window.

We begin by presenting descriptive evidence on this hypothesis. Figure 2 charts the stock price reaction to the accounting restatement, beginning 92 days prior to the restatement announcement until 2 days after the restatement announcement. We chart the cumulative abnormal returns for firms with $9 \%$ or greater transient institutional ownership (HIGH_TRA) and firms with less than 9\% transient institutional ownership ( $\left.L O W_{-} T R A\right)$, respectively, with levels of transient institutional ownership measured at the end of two quarters prior to the restating quarter (i.e.,

\footnotetext{
${ }^{12}$ Regulation Fair Disclosure (Reg FD), effective on October 23, 2000, states that managers may not privately disclose material information to select financial analysts and institutional investors. The SEC commissioners believed that managers provided material, advanced knowledge of earnings results and other important nonpublic information to select investors, who then traded profitably at the expense of less informed investors.
} 
prior to the date when the cumulative abnormal returns start to accumulate). $9 \%$ of transient institutional ownership is the sample median. The two lines show that HIGH_TRA firms exhibit more negative returns over the 90 days prior to the restatement announcement (i.e., day -92 to day -3). Specifically, three days prior to the announcement, HIGH_TRA firms have a cumulative abnormal return of $-16.4 \%$. This compares to the $L O W_{-} T R A$ firms, which have cumulative abnormal return of $-9.5 \%$ three days prior to the announcement. During the event window which is defined as day -2 to +2 around the restatement announcement date, however, the HIGH_TRA firms exhibit similar negative returns as the $L O W_{-} T R A$ firms. In particular, in the five day window (day -2 to day +2 ), the cumulative abnormal returns of $H I G H \_T R A$ firms goes from $16.4 \%$ to $-24.3 \%$, while those of $L O W_{-} T R A$ firms drop from $-9.5 \%$ to $-16.0 \%$. Overall, these results suggest that the presence of transient institutional investors gets the information content of restatement impounded into stock price early in the pre-announcement period.

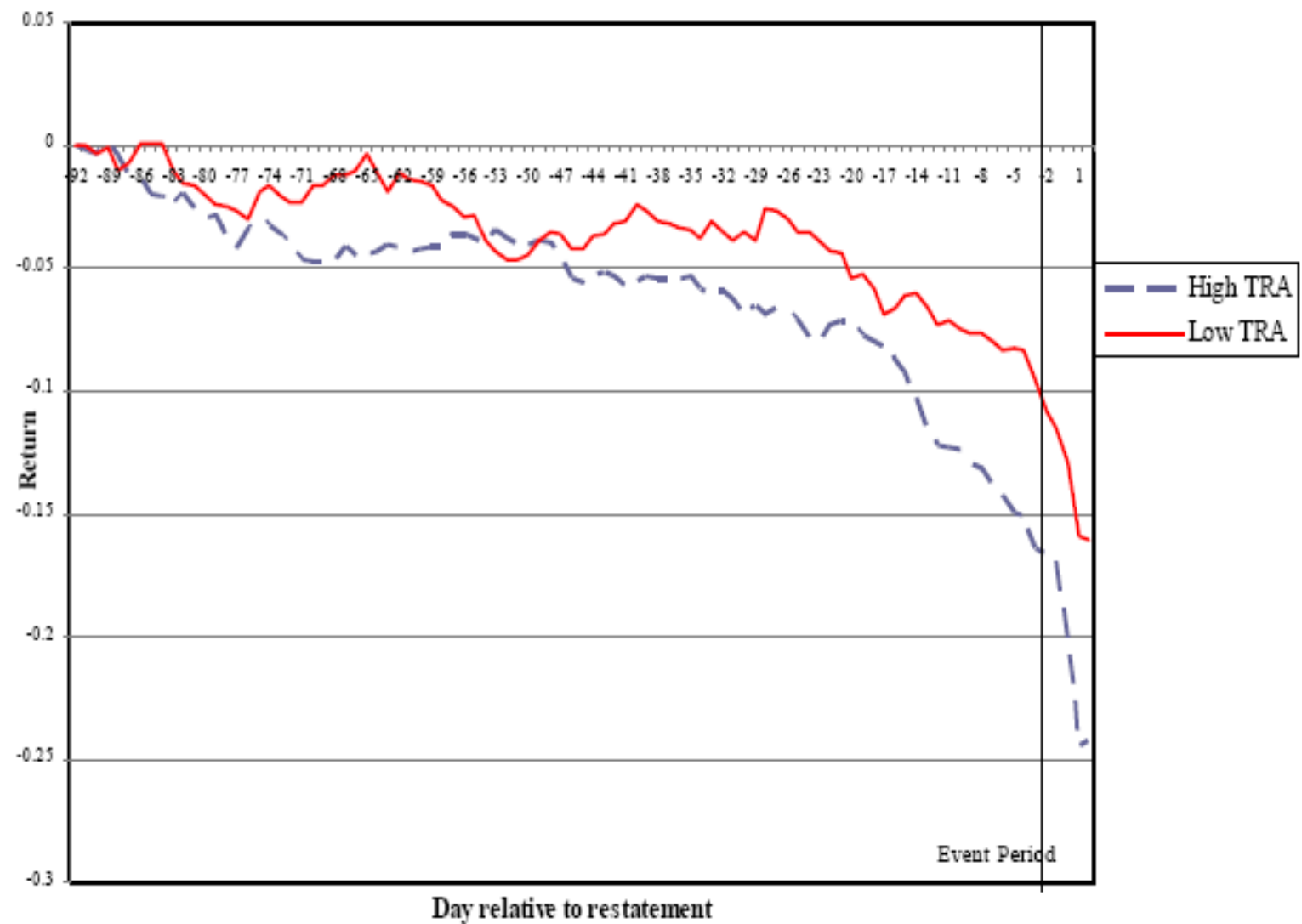

Figure 2. Cumulative abnormal returns by high and low transient institutional ownership

Note. This figure charts the cumulative abnormal returns to firms that have an accounting restatement from - 92 days to until 2 days after the restatement. The sample consists of 364 restatements over the period 1997 to 2002. Low_TRA signifies firms with less than 9\% (the sample median) transient institutional ownership, while High_TRA indicates firms with greater than or equal to $9 \%$ transient institutional ownership.

To formalize this result, we also use a regression based design that attempts to control for other influences on price. We estimate the 90-day cumulative abnormal returns in the period prior to the restatement announcement (day -92 to day -3) as a function of the level of different 
institutional ownership. We control for size ( $L N S I Z E$ ), book-to-market ( $B M$ ), return momentum ( $R E T Q 24$ ), unexpected earnings ( $U E$ ), year and industry fixed effects. These variables are defined in Equation (1). We also include a restatement reason indicator CORE, which is equal to 1 when the restatement involves revenue recognition, cost of sales or operating expenses, or loan loss provisions and equal to 0 otherwise (Hribar and Jenkins, 2004); and a restatement initiator indicator $A U D I T O R$, which is equal to 1 when the restatement is initiated by the auditor and equal to zero otherwise, in order to capture the fact that these restatements tend to cause more negative returns (Palmrose, Richardson, and Scholz, 2004). To measure the effect of institutional holdings on the abnormal returns, we form scaled deciles based on the level of institutional ownership for transient $\left(T R A_{-} R A N K\right)$, dedicated ( $D E D_{-} R A N K$ ) and quasiindexing institutional ownership ( $Q I X_{-} R A N K$ ), respectively (Ayers and Freeman, 2003). With regard to TRA_ $R A N K$, we group the 364 restating firms into ten groups based on the level of aggregate transient institutional holdings of the restating firm's shares outstanding at the end of quarter q-2 $\left(T R A \%_{q-2}\right)$ (i.e., group 0 9). We then divide this decile ranking by 9. For example, TRA_RANK $\mathrm{q}_{-2}$ is equal to 0 (i.e., 0/9) for the firms with the lowest TRA\% $\%_{\mathrm{q}-2}$ and equal to 1 (i.e., 9/9) for the firms with the highest TRA\% $\%_{\mathrm{q}-2}$. Likewise, we measure $D E D_{-} R A N K$ and $Q I X \_R A N K$. ${ }^{13}$ All the independent variables except RETQ24, CORE and AUDITOR are measured at the end of two quarters prior to the restating quarter, so that the independent variables are measured before the date when the pre-announcement cumulative abnormal returns (CAR90) starts to accumulate. The regression model is as follows:

$$
\begin{aligned}
& C A R 90=\beta_{0}+\beta_{1} T R A_{-} R A N K_{j, q-2}+\beta_{2} D E D_{-} R A N K_{j, q-2}+\beta_{3} Q I X_{-} R A N K_{j, q-2}+\beta_{4} R E T Q 24_{j, q} \\
& \beta_{5} L_{N S I Z E_{j, q-2}}+\beta_{6} B_{j, q-2}+\beta_{7} U E_{j, q-2}+\beta_{8} A U D I T O R+\beta_{9} C O R E+\text { YearDummies }+ \text { IndustryDummies }
\end{aligned}
$$

Table 5 presents the results of estimating Equation (3). Table 5, column (1) provides the results for the full restatement sample (i.e., 364 restatements). Consistent with the expectations, firms with a large number of transient institutional investors exhibit significantly more negative returns in the pre-announcement period (coefficient $=-0.192$, p-value $=0.02$ ). This is not true of any of the other types of institutional investors, with $Q I X_{-} R A N K_{j, q-2}$ and $D E D_{-} R A N K_{j, q-2}$ not significantly different from zero. Also, the magnitude of the coefficient is substantial, with the difference to be $19.2 \%$ between firms with high transient institutional ownership and firms with low transient institutional ownership. In addition, it appears that restatements that involves revenue recognition, cost of sales or operating expenses, or loan loss provisions have significantly larger preannouncement negative returns relative to the other restatements. Taken as a whole, the results suggest that the presence of transient institutional ownership accelerates the impounding of the restatement news into price, causing more negative pre-announcement returns for firms with high transient institutional ownership than firms with low transient institutional ownership. Table 5, column (2) provides the results for the sub-sample of the

\footnotetext{
${ }^{13}$ The results are qualitatively similar using scaled quintile ranking to construct TRA_RANK, DED_RANK, and QIX_RANK. That is, we form the 364 restating firms into 5 groups (i.e., group 0 4) based on the level of aggregate transient (TRA $\%_{\mathrm{q}-2}$ ), dedicated (DED $\%_{\mathrm{q}-2}$ ), and quasi-indexing institutional holdings (QIX\% $\%_{\mathrm{q}-2}$ ) of the firm's shares outstanding and then divide this quintile ranking of transient, dedicated and quasi-indexing by 4 , respectively.
} 
restatements that occur before the implementation of Reg FD (i.e., before October 23, 2000; 202 restatements). Consistent with the prediction, firms with a large number of transient institutional investors continues to exhibit significantly more negative returns in the pre-announcement period (coefficient $=-0.171, \mathrm{p}$-value $=0.09$ ). Likewise, table 5, column (3) provides the results for the sub-sample of the restatements that occur after the implementation of Reg FD (i.e., after October 23,$2000 ; 162$ restatements). As expected, firms with a large number of transient institutional investors continues to exhibit significantly more negative returns in the pre-announcement period (coefficient $=-0.380, \mathrm{p}$-value $=0.01$ ).

Table 5. The Market Reaction to Accounting Restatements and Levels of Different Institutional Holdings

\begin{tabular}{|c|c|c|c|}
\hline & \multicolumn{3}{|c|}{ Dependent variable- CARP90 } \\
\hline Independent variables & $\begin{array}{l}\text { (Full restatement sample) } \\
\text { (1) }\end{array}$ & $\begin{array}{c}\text { (Pre-regulation FD } \\
\text { sub-sample) } \\
(2)\end{array}$ & $\begin{array}{c}\text { (Post-regulation FD } \\
\text { sub-sample) } \\
\text { (3) }\end{array}$ \\
\hline INTERCEPT & $\begin{array}{l}-0.285^{*} \\
(-1.67)\end{array}$ & $\begin{array}{l}-0.494 * * \\
(-1.75)\end{array}$ & $\begin{array}{l}-0.394 * * \\
(-1.83)\end{array}$ \\
\hline TRA_RANK ${ }_{\mathrm{q}-2}$ & $\begin{array}{l}-0.192 * * \\
(-2.01) \\
\end{array}$ & $\begin{array}{l}-0.171^{*} \\
(-1.34) \\
\end{array}$ & $\begin{array}{l}-0.380 * * \\
(-2.34) \\
\end{array}$ \\
\hline DED_RANK $_{\mathrm{q}-2}$ & $\begin{array}{l}-0.063 \\
(-0.77) \\
\end{array}$ & $\begin{array}{l}-0.133 \\
(-1.21) \\
\end{array}$ & $\begin{array}{l}0.061 \\
(0.49) \\
\end{array}$ \\
\hline QIX_RANK ${ }_{\mathrm{q}-2}$ & $\begin{array}{l}0.059 \\
(0.51) \\
\end{array}$ & $\begin{array}{l}0.010 \\
(0.06) \\
\end{array}$ & $\begin{array}{l}0.136 \\
(0.80) \\
\end{array}$ \\
\hline RETQ24 q & $\begin{array}{l}0.118^{* * * *} \\
(3.47) \\
\end{array}$ & $\begin{array}{l}0.196 * * * \\
(4.18) \\
\end{array}$ & $\begin{array}{l}0.016 \\
(0.30) \\
\end{array}$ \\
\hline LNSIZE $_{\mathrm{q}-2}$ & $\begin{array}{l}0.029 * * \\
(1.82) \\
\end{array}$ & $\begin{array}{l}0.050^{* *} \\
(2.02) \\
\end{array}$ & $\begin{array}{l}0.032^{*} \\
(1.56) \\
\end{array}$ \\
\hline $\mathrm{BM}_{\mathrm{q}-2}$ & $\begin{array}{l}0.095^{* * * *} \\
(2.86) \\
\end{array}$ & $\begin{array}{l}0.179 * * * \\
(2.88) \\
\end{array}$ & $\begin{array}{l}0.031 \\
(0.72) \\
\end{array}$ \\
\hline $\mathrm{UE}_{\mathrm{q}-2}$ & $\begin{array}{l}-0.549 * * * \\
(-3.51) \\
\end{array}$ & $\begin{array}{l}-0.848 * * * \\
(-2.68) \\
\end{array}$ & $\begin{array}{l}-0.475 * * \\
(-2.61) \\
\end{array}$ \\
\hline AUDITOR & $\begin{array}{l}-0.078 \\
(-0.85) \\
\end{array}$ & $\begin{array}{l}-0.158^{*} \\
(-1.44) \\
\end{array}$ & $\begin{array}{l}0.065 \\
(0.36) \\
\end{array}$ \\
\hline CORE & $\begin{array}{l}-0.141 * * * \\
(-2.89)\end{array}$ & $\begin{array}{l}-0.091 * \\
(-1.33)\end{array}$ & $\begin{array}{l}-0.106^{*} \\
(-1.40)\end{array}$ \\
\hline Year Fixed Effects & Included & Included & Included \\
\hline Industry Fixed Effects & Included & Included & Included \\
\hline Adjusted $\mathrm{R}^{2}$ & 0.156 & 0.251 & 0.074 \\
\hline
\end{tabular}

Note. This table examines the market reaction to the restatement announcement over the 90-day pre-announcement period (i.e., day -92 to day -3 prior to the restatement announcement) on levels of different institutional holdings using Equation (3) below. The first column presents the result for the full restatement sample (i.e., 364 restatements announced from 1997 to 2002). The second column presents the results for the restatements that occur before the implementation of Regulation FD (i.e., 202 restatements announced from 1997 to October 23, 2000). The third column presents the results for the restatements that occur after the implementation of Regulation FD (i.e., 162 restatements announced from October 23, 2000 to 2002). For brevity, YEAR and INDUSTRY variables are omitted from the table. $* * *, * *$, and $*$ denote one-tailed significance at the $0.01,0.05$ and 0.1 levels, respectively. t-statistics are presented in parentheses. 
Taken as a whole, the results suggest that the presence of high transient institutional ownership gets the information content of restatement impounded into stock price early in the preannouncement period. Furthermore, the finding that firms with higher transient institutional ownership exhibit more negative returns for both the restatements occurring before and after Reg FD provides additional evidence that information advantage via private communications with management is unlikely to be the source of informed trading by institutions with respect to a restatement. Therefore, the information advantage of institutional investors is likely attributable to institutions' superior ability to process public information.

\subsection{Additional Tests}

We perform additional tests to ensure further the robustness of our inferences. For brevity, we focus on transient institutional investors only because the preceding results indicate that only transient institutional investors appear to anticipate impending restatements.

\subsubsection{Institutional Investors' Trading Around the Restatements That Affect Core Earnings}

We extend our analysis to examine whether institutional investors are differentially able to predict restatements that affect core earnings, as opposed to those that do not affect core earnings. Following Hribar and Jenkins (2004), we define core earnings as restatements related to revenue recognition, cost of sales or operating expenses, or loan loss provisions. We then examine the following regression:

$$
\begin{aligned}
& \triangle A D J_{-} \text {INSTITUTION }_{j, q}=\beta_{0} \text { RESTATE }+\beta_{1} \text { PRERESTATE } 1+\beta_{2} \text { PRERESTATE } 2 \\
& +\beta_{3} C O R E+\beta_{4} C O R E * R E S T A T E+\beta_{5} C O R E * P R E R E S T A T E 1+\beta_{6} \text { CORE * PRERESTATE } 2 \\
& +\beta_{7} \text { INSTITUTION }_{j, q-1}+\beta_{8} \text { PW }_{-} \text {INSTITUTION }_{j, q-1}+\beta_{9} \text { RETQ }_{j, q}+\beta_{10}{\text { RETQ } 24_{j, q}} \\
& +\beta_{11} L N S I Z E_{j, q-1}+\beta_{12} B M_{j, q-1}+\beta_{13} U E_{j, q-1}+\text { YearDummies + IndustryDummies }
\end{aligned}
$$

All the variables are defined in equation (1), (2), and (3). We include the main effect of CORE in the model for completeness, but do not have an ex ante prediction of its coefficient. However, we expect that the interactions between CORE and RESTATE, PRERESTATE1 and PRERESTATE2 will be significantly negative if institutional investors sell more holdings preceding restatements that affect recurring/core operating earnings than those that do not affect core earnings. Untabulated results show that transient institutions reduce their holdings in the restatement quarter by a significantly greater amount when the restatement affects CORE earnings. Also, the coefficient on PRERESTATE1 remains negatively significant, consistent with our prediction that transient institutions sell holdings in advance of restatements. However, the interaction between CORE*PRERESTATE1 is not statistically significant. Other results are not qualitatively different from those reported in Table 3. In summary, although a restatement of $C O R E$ earnings affects the magnitude of the sell-off in the restating quarter, it appears to have no differential impact on institutions' trading in advance of the restatement announcement.

\subsubsection{Institutional Investors' Trading After the Restatements}

We also extend the analysis on how institutional investors trade after the restatement announcement quarter by adding two post-restatement dummies in equation (1) and equation (2), i.e., POSTRESTATE1 (POSTRESTATE2), which is equal to 1 if the institutional ownership measurement quarter is one (two) quarter (s) after the restatement announcement quarter and equal to zero otherwise. We provide the regression results in table 6 . Table 6 , column (1) and (2) 
reports the result based on equation (1) and (2), respectively, after including POSTRESTATE1 and POSTRESTATE2 . The coefficients on POSTRESTATE1 and POSTRESTATE2 are not significant in both column (1) and (2), suggesting that transient institutional investors do not trade significantly after the restatement announcement quarter. As expected, transient institutional investors sell holdings one quarter before the restatement announcement quarter after adding these two post-restatement dummies. Overall, the results in table 6 demonstrate that transient institutional investors respond to restatements by selling more holdings preceding the restatements, but not after the restatements.

Table 6 Transient Institutional Trading After Announcements of Accounting Restatements

\begin{tabular}{|c|c|c|}
\hline \multirow{2}{*}{$\begin{array}{l}\text { Independent } \\
\text { variables }\end{array}$} & \multicolumn{2}{|c|}{ Dependent variable $-\Delta$ ADJ $\quad T R A \%_{q}$} \\
\hline & (1) & (2) \\
\hline INTERCEPT & $\begin{array}{l}0.068 \\
(0.13)\end{array}$ & $\begin{array}{l}-0.002 \\
(0.00)\end{array}$ \\
\hline RESTATE & $\begin{array}{l}-0.765 * * * \\
(-4.28)\end{array}$ & $\begin{array}{l}-0.858 * * * \\
(-4.26)\end{array}$ \\
\hline PRERESTATE1 & $\begin{array}{l}-0.382 * * \\
(-2.13)\end{array}$ & $\begin{array}{l}-0.384 * \\
(-1.89)\end{array}$ \\
\hline PRERESTATE2 & $\begin{array}{l}-0.032 \\
(-0.18)\end{array}$ & $\begin{array}{l}-0.046 \\
(-0.22)\end{array}$ \\
\hline POSTRESTATE1 & $\begin{array}{l}0.070 \\
(0.38)\end{array}$ & $\begin{array}{l}0.102 \\
(0.49)\end{array}$ \\
\hline POSTRESTATE2 & $\begin{array}{l}0.010 \\
(0.05)\end{array}$ & $\begin{array}{l}0.041 \\
(0.19)\end{array}$ \\
\hline TRANSIENT\% $\%$ & $\begin{array}{l}-0.064 * * * \\
(-10.81)\end{array}$ & $\begin{array}{l}-0.068 * * * \\
(-10.16)\end{array}$ \\
\hline PW_TRANSIENT\% $\%_{\mathrm{q}-1}$ & $\begin{array}{l}-1.668 * * * \\
(-2.66)\end{array}$ & $\begin{array}{l}-2.144 * * * \\
(-3.05)\end{array}$ \\
\hline RETQ1 $_{\mathrm{q}}$ & $\begin{array}{l}1.265 * * * \\
(8.85)\end{array}$ & $\begin{array}{l}1.279 * * * \\
(8.26)\end{array}$ \\
\hline RETQ24 $\mathrm{q}$ & $\begin{array}{l}0.076 \\
(0.97)\end{array}$ & $\begin{array}{l}0.229 * * \\
(2.54)\end{array}$ \\
\hline LNSIZE $_{\mathrm{q}-1}$ & $\begin{array}{l}0.182 * * * \\
(5.47)\end{array}$ & $\begin{array}{l}0.248 * * * \\
(6.46)\end{array}$ \\
\hline $\mathrm{BM}_{\mathrm{q}-1}$ & $\begin{array}{l}-0.199 * * * \\
(-3.01)\end{array}$ & $\begin{array}{l}-0.169 * * \\
(-2.37)\end{array}$ \\
\hline $\mathrm{UE}_{\mathrm{q}-1}$ & $\begin{array}{l}0.023 \\
(0.09) \\
\end{array}$ & $\begin{array}{l}-0.120 \\
(-0.45) \\
\end{array}$ \\
\hline $\operatorname{DSRI}_{\mathrm{q}}$ & & $\begin{array}{l}-0.188 * \\
(-1.76)\end{array}$ \\
\hline $\mathrm{GMI}_{\mathrm{q}}$ & & $\begin{array}{l}0.026 \\
(0.39) \\
\end{array}$ \\
\hline $\mathrm{AQI}_{\mathrm{q}}$ & & $\begin{array}{l}0.008 \\
(1.42)\end{array}$ \\
\hline $\mathrm{SGI}_{\mathrm{q}}$ & & $\begin{array}{l}0.029 \\
(0.56) \\
\end{array}$ \\
\hline $\operatorname{DEPI}_{\mathrm{q}}$ & & $\begin{array}{l}-0.083 \\
(-0.32)\end{array}$ \\
\hline TATA $_{\mathrm{q}}$ & & $\begin{array}{l}-1.120 * * * \\
(-3.55)\end{array}$ \\
\hline
\end{tabular}




\begin{tabular}{|l|l|l|}
\hline Year Fixed Effects & Included & Included \\
\hline Industry Fixed Effects & Included & Included \\
\hline Adjusted $\mathrm{R}^{2}$ & 0.085 & 0.095 \\
\hline
\end{tabular}

Note. This table presents the sensitivity check on how transient institutional investors trade after restatement announcements. Specifically, we add two dummy variables POSTRESTATE1 and POSTRESTATE2 in equation (1) and (2), respectively, in order to capture how transient institutional investors trade after accounting restatement announcements. POSTRESTATE1 (POSTRESTATE2) is equal to 1 if the institutional ownership measurement quarter is one (two) quarter (s) after the restatement announcement quarter and equal to zero otherwise. For brevity, YEAR and INDUSTRY variables are omitted from the table. Outliers in the regressions are deleted when the absolute value of studentized residuals or DFFITS influence statistics is greater than or equal to 1.9. ***, **, and * denote two-tailed significance at the $0.01,0.05$ and 0.1 levels, respectively. t-statistics are presented in parentheses.

\section{Conclusions}

This paper provides direct evidence that actively trading institutional investors reduce their holdings prior to a restatement and that they play a role in the price formation process surrounding the restatement event. First, we show that transient institutions, which are shortterm focused, reduce their holdings at least one quarter prior to the restating quarter. Because of the setting in which our analysis is performed (i.e. accounting restatements), it is unlikely that the information advantage of transient institutions is due to private communications with firm management. Rather, the information advantage that we document most likely results from institutional investors' superior ability to process public information due to better knowledge and/or resources. Second, of the factors that have been shown to be associated with earnings manipulation, we show that changes in days sales in receivables and accruals lead to reductions in holdings by transient institutional investors, consistent with institutional investors making informed trading based on financial statement information to reduce their exposure to a potential restatement. Lastly, our analysis shows that the market reaction to the accounting restatement is more negative prior to the restatement announcement for firms with higher levels of transient institutional ownership. Overall, our results demonstrate that institutional investors anticipate impending restatements and play an important role in the price formation process for firms that are forced to restate their financial statements.

\section{Acknowledgement}

We have benefited from useful comments and suggestions provided by Dan Bens, Patty Dechow, Jim Ohlson, Beverly Walther, Charles Wasley, Jerry Zimmerman and workshop participants at the University of Arizona, Arizona State University, Penn State University, Rice University, University of Rochester, Washington University in St. Louis, and the 2005 FARS mid-year meeting. We especially thank Brian Bushee for the institutional investor classification data.

\section{References}

Abarbanell, J., Bushee, B., \& Raedy, J. (2003). Institutional investor preferences and price pressure: The case of corporate spin-offs. Journal of Business, 76, 233-261

Ali, A., Durtschi, C., Lev, B., \& Trombley, M. (2004). Changes in institutional ownership and subsequent earnings announcement abnormal returns. Journal of Accounting, Auditing and Finance, 19, 221-248 
Amihud, Y.A., \& Li, K. (2006). The declining information content of dividend announcements and the effect of institutional holdings. Journal of Financial and Quantitative Analysis, 41, 636660

Ayers, B.C., \& Freeman, R.N. (2003). Evidence that analyst following and institutional ownership accelerate the pricing of future earnings. Review of Accounting Studies, 8, 47-67

Badrindath, S.G., \& Wahal, S. (2002). Momentum trading by institutions. The Journal of Finance, 57, 2449-2478

Balsam, S., Bartov, E., \& Marquardt, C. (2002). Accruals management, investor sophistication, and equity valuation: Evidence from 10-Q filings. Journal of Accounting Research, 40, 987-1012

Barth, M.E., Beaver, W.H., \& Hand, J.R. (1999). Accruals, cash flows, and equity values. Review of Accounting Studies, 3, 205-229

Bartov, E., Radhakrishnan, S., \& Krinsky, I. (2000). Investor sophistication and patterns in stock returns after earnings announcements. The Accounting Review, 75, 43-63

Beneish, D. (1999). The detection of earnings manipulation. Financial Analyst's Journal, 55, 2436

Bushee, B. (1998). The influence of institutional investors on myopic R\&D investment behavior. The Accounting Review, 73, 305-333

Bushee, B., \& Noe, C. (2000). Corporate disclosure practices, institutional investors, and stock return volatility. Journal of Accounting Research, 38 (Supplement), 171-202

Bushee, B. (2001). Do institutional investors prefer near-term earnings over long-run value? Contemporary Accounting Research, 18, 207-246

Bushee, B.J., \& Goodman, T.H. (2007). Which institutional investors trade based on private information about earnings and returns? Journal of Accounting and Research, 45, 289-321

Chen, X., Cheng, Q., \& Lo, A. (2009). The consequences of aggressive financial reporting: The case of external financing. University of Wisconsin-Madison working paper

Collins, D.W., Gong, G., \& Hribar, P. (2003). Investor sophistication and the mispricing of accruals. Review of Accounting Studies, 8, 251-276

Cohen, R., Coval, J., \& Pastor, L. (2005). Judging fund managers by the company that they keep. Journal of Finance, 60, 1057-1096

Coles, J., Daniel, N., \& Naveen, L. (2008). Boards: Does one size fit all? Journal of Financial Economics, 87, 329-356

El-Gazzar, S. (1998). Predisclosure information and institutional ownership: A cross-sectional examination of market revaluations during earnings announcement periods. The Accounting Review, 73, 119-29

Gompers, P., \& Metrick, A. (2001). Institutional investor and equity prices. The Quarterly Journal of Economics, 116, 229-59

Hribar, P., \& Jenkins, N. (2004). The effect of accounting restatements on earnings revisions and the estimated cost of capital. Review of Accounting Studies, 9, 337-356 
Jiambalvo, J., Rajgopal, S., \& Venkatachalam, M. (2002). Institutional ownership and the extent to which stock prices reflect future earnings. Contemporary Accounting Research, 19, 117-45

Kacperczyk, M., Sialm, C., \& Zheng, L. (2005). On the industry concentration of actively managed equity mutual funds. The Journal of Finance, 60, 1983-2011

Ke, B., \& Petroni, K. (2004). How informed are actively trading institutional investors? Evidence from their trading behavior before a break in a string of consecutive earnings increases. Journal of Accounting Research, 42, 895-927

Ke, B., \& Ramalingegowda, S. (2005). Do money managers exploit the post-earnings announcement drift? Journal of Accounting and Economics, 39, 25-53

Ke, B., Petroni, K., \& Yu, Y. (2008). The effect of Regulation FD on transient institutional investors' trading behavior. Journal of Accounting Research, 46, 853-883

Kennedy, P. (2003). A guide to econometrics. Cambridge: MIT Press

Myers, J., Myers, L., Palmrose, \& Z., Scholz, S. (2003). Mandatory auditor rotation: Evidence from restatements. University of Illinoise at Urbana-Champaign working paper

Palmrose, Z.V., Richardson, V.J., \& Scholz, S. (2004). Determinants of Market Reactions to Restatement Announcements. Journal of Accounting and Economics, 37, 59-89

Palmrose, Z.V., \& Scholz, S. (2004). The circumstances and legal consequences of non-GAAP reporting: Evidence from restatements. Contemporary Accounting Research, 21, 139-180

Plumlee, M., \& Yohn, T.L. (2009). An analysis of the underlying causes attributed to restatements. University of Utah working paper

Walther, B. (1997). Investor sophistication and market earnings expectations. Journal of Accounting Research, 35, 157-79

Wang, J. (2010). Transient institutional investors and insider trading signals. International Journal of Accounting and Information Management (forthcoming)

\section{Appendixes}

Appendix 1.Variable Definitions

\begin{tabular}{|l|l|}
\hline Variables & Measurement \\
\hline Institutional Ownership Variables \\
\hline INST\% \\
\hline qADJ_INST\% & $\begin{array}{l}\text { = level of total institutional ownership of the firm's shares outstanding at the end of } \\
\text { quarter q-1. }\end{array}$ \\
\hline $\begin{array}{l}\text { = mean-adjusted change in total institutional holdings of the firm's shares outstanding } \\
\text { over calendar quarter q. The adjustment is made by subtracting the average change in } \\
\text { total institutional holdings across all firms in the CDA/Spectrum database over the } \\
\text { same calendar quarter q, in order to control for time trends in the change in total } \\
\text { institutional holdings (Abarbanell, Bushee, and Raedy, 2003). }\end{array}$ \\
\hline $\begin{array}{l}\text { PW_INST\% } \%_{\mathrm{q}-1} \\
\text { quarter q-1. PW_INST } \\
\text { value of firm } \mathrm{j} \text { held by all institutions at the end of quarter q-1. MV } \\
\text { market value of all firms held by the same institutions at the end of quarter q-1. }\end{array}$ \\
\hline TRA\% $\%_{\mathrm{q}-1}$ & $\begin{array}{l}\text { = level of aggregate transient institutional holdings of the firm's shares outstanding at } \\
\text { the end of quarter q-1. }\end{array}$ \\
\hline
\end{tabular}




\begin{tabular}{|c|c|}
\hline$\Delta$ ADJ_TRA\% $\%_{q}$ & $\begin{array}{l}\text { = mean-adjusted change in aggregate transient institutional holdings of the firm's } \\
\text { shares outstanding over calendar quarter q. The adjustment is made by subtracting the } \\
\text { average change in aggregate transient institutional holdings across all firms in the } \\
\text { CDA/Spectrum database over the same calendar quarter q, in order to control for time } \\
\text { trends in the change in transient institutional holdings (Abarbanell, Bushee, and } \\
\text { Raedy, 2003). }\end{array}$ \\
\hline PW_TRA $\%_{\mathrm{q}-1}$ & 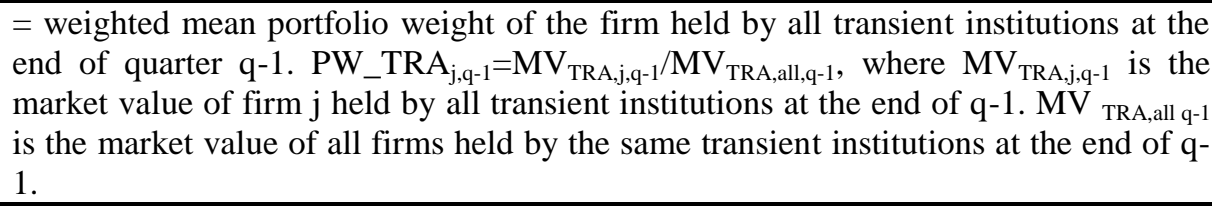 \\
\hline TRA_RANK $_{\mathrm{q}-2}$ & $\begin{array}{l}\text { =scaled decile ranking across the restating firms (i.e., } 364 \text { restating firms) based on } \\
\text { the level of aggregate transient institutional holdings of the firm's shares outstanding } \\
\text { at the end of quarter q-2 (TRA\% } \%_{\mathrm{q}-2} \text { ). Specifically, we group the } 364 \text { restating firms } \\
\text { into ten groups based on TRA\% } \%_{\mathrm{q}-2}(\text { i.e., group } 0 \sim 9 \text { ) and then divide this decile ranking } \\
\text { by } 9 \text {. For example, TRA_RANK }{ }_{\mathrm{q}-2} \text { is equal to } 0 \text { (i.e., } 0 / 9 \text { ) for the firms with the } \\
\text { lowest TRA } \%_{\mathrm{q}-2} \text { and equal to } 1 \text { (i.e., } 9 / 9 \text { ) for the firms with the highest TRA\% } \%_{\mathrm{q}-2 .} \text {. }\end{array}$ \\
\hline $\mathrm{DED} \%_{\mathrm{q}-1}$ & $\begin{array}{l}=\text { level of aggregate dedicated institutional holdings of the firm's shares outstanding } \\
\text { at the end of quarter q-1. }\end{array}$ \\
\hline$\Delta$ ADJ_DED\% $\%_{\mathrm{q}}$ & $\begin{array}{l}\text { = mean-adjusted change in aggregate dedicated institutional holdings of the firm's } \\
\text { shares outstanding over calendar quarter q. The adjustment is made by subtracting the } \\
\text { average change in aggregate dedicated institutional holdings across all firms in the } \\
\text { CDA/Spectrum database over the same calendar quarter q, in order to control for time } \\
\text { trends in the change in dedicated institutional holdings (Abarbanell, Bushee, and } \\
\text { Raedy, 2003). }\end{array}$ \\
\hline PW_DED $\%_{\mathrm{q}-1}$ & 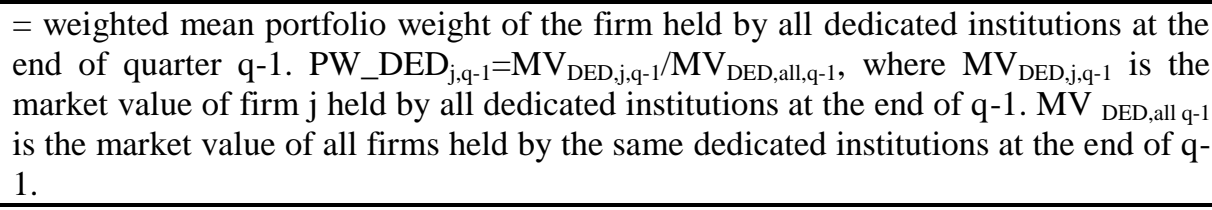 \\
\hline DED_RANK $_{\mathrm{q}-2}$ & $\begin{array}{l}\text { =scaled decile ranking across the restating firms (i.e., } 364 \text { restating firms) based on } \\
\text { the level of aggregate dedicated institutional holdings of the firm's shares outstanding } \\
\text { at the end of quarter q-2 (DED } \%_{\mathrm{q}-2} \text { ). Specifically, we group the } 364 \text { restating firms } \\
\text { into ten groups based on DED\% }{ }_{\mathrm{q}-2}(\text { i.e., group } 0 \sim 9 \text { ) and then divide this decile } \\
\text { ranking by } 9 \text {. For example, DED_RANK } \text { q }_{\mathrm{q}-2} \text { is equal to } 0 \text { (i.e., } 0 / 9 \text { ) for the firms with } \\
\text { the lowest DED } \%_{\mathrm{q}-2} \text { and equal to } 1 \text { (i.e., } 9 / 9 \text { ) for the firms with the highest DED } \%_{\mathrm{q}-2} \text {. }\end{array}$ \\
\hline$\overline{\text { QIX\% }} \%_{\mathrm{q}-1}$ & $\begin{array}{l}=\text { level of aggregate quasi-indexing institutional holdings of the firm's shares } \\
\text { outstanding at the end of quarter q-1. }\end{array}$ \\
\hline$\Delta$ ADJ_QIX\% $\%_{q}$ & $\begin{array}{l}\text { = mean-adjusted change in aggregate quasi-indexing institutional holdings of the } \\
\text { firm's shares outstanding over calendar quarter q. The adjustment is made by } \\
\text { subtracting the average change in aggregate quasi-indexing institutional holdings } \\
\text { across all firms in the CDA/Spectrum database over the same calendar quarter q, in } \\
\text { order to control for time trends in the change in quasi-indexing institutional holdings } \\
\text { (Abarbanell, Bushee, and Raedy, 2003). }\end{array}$ \\
\hline PW_QIX\% $\%_{\mathrm{q}-1}$ & $\begin{array}{l}\text { = weighted mean portfolio weight of the firm held by all quasi-indexing institutions at } \\
\text { the end of quarter } \mathrm{q}-1 \text {. PW_QIX } \\
\text { market value of firm } \mathrm{j} \text { held by all } 1=\mathrm{MV}_{\mathrm{QIX}, \mathrm{j}, \mathrm{q}-1} / \mathrm{MV}_{\mathrm{QIX}, \text { all, } \mathrm{q}-1} \text {, where } \mathrm{MV}_{\mathrm{QIX}, \mathrm{j}, \mathrm{q}-1} \text { is the } \\
\text { QIX,-ill q-1 is the market value of all firms held by the same quasi-indexing institutions at } \\
\text { the end of } \mathrm{q}-1 \text {. }\end{array}$ \\
\hline QIX_RANK ${ }_{\mathrm{q}-2}$ & $\begin{array}{l}\text { =scaled decile ranking across the restating firms (i.e., } 364 \text { restating firms) based on } \\
\text { the level of aggregate quasi-indexing institutional holdings of the firm's shares } \\
\text { outstanding at the end of quarter q-2 (QIX\% } \%_{\mathrm{q}-2} \text { ). Specifically, we group the } 364 \\
\text { restating firms into ten groups based on QIX } \%_{\mathrm{q}-2}(\text { i.e., group 0 9) and then divide this }\end{array}$ \\
\hline
\end{tabular}




\begin{tabular}{|c|c|}
\hline & $\begin{array}{l}\text { decile ranking by } 9 \text {. For example, QIX_RANK }{ }_{\mathrm{q}-2} \text { is equal to } 0 \text { (i.e., 0/9) for the firms } \\
\text { with the lowest QIX } \%_{\mathrm{q}-2} \text { and equal to } 1 \text { (i.e., 9/9) for the firms with the highest } \\
\text { QIX } \%_{\mathrm{q}-2 \text {. }}\end{array}$ \\
\hline \multicolumn{2}{|c|}{ Restatement variables } \\
\hline CORE & $\begin{array}{l}=\text { restatement reason indicator, which is equal to } 1 \text { if the restatement involves revenue } \\
\text { recognition, cost of sales or operating expenses, or loan loss provisions and equal to } 0 \\
\text { otherwise. }\end{array}$ \\
\hline AUDITOR & $\begin{array}{l}=\text { restatement initiator indicator, which is equal to } 1 \text { if the restatement is initiated by } \\
\text { the auditor and equal to } 0 \text { otherwise. }\end{array}$ \\
\hline RETSTATE & $\begin{array}{l}=\text { restatement quarter indicator, which is equal to } 1 \text { if the firm announced a } \\
\text { restatement in that quarter (restating quarter) and equal to } 0 \text { otherwise. }\end{array}$ \\
\hline PRERESTATE1 & $\begin{array}{l}=\text { pre-restatement quarter indicator, which is equal to } 1 \text { if the observation quarter is } \\
\text { one quarter prior to the restating quarter and equal to } 0 \text { otherwise. }\end{array}$ \\
\hline PRERESTATE2 & $\begin{array}{l}=\text { pre-restatement quarter indicator, which is equal to } 1 \text { if the observation quarter is } \\
\text { two quarters prior to the restating quarter and equal to } 0 \text { otherwise. }\end{array}$ \\
\hline POSTRESTATE1 & $\begin{array}{l}=\text { post-restatement quarter indicator, which is equal to } 1 \text { if the observation quarter is } \\
\text { one quarter after the restating quarter and equal to } 0 \text { otherwise. }\end{array}$ \\
\hline POSTRESTATE2 & $\begin{array}{l}=\text { post-restatement quarter indicator, which is equal to } 1 \text { if the observation quarter is } \\
\text { two quarters after the restating quarter and equal to } 0 \text { otherwise. }\end{array}$ \\
\hline \multicolumn{2}{|l|}{ Control variables } \\
\hline LNSIZE $_{\mathrm{q}-1}$ & $=\log$ of book value of total assets (DATA44) at the end of quarter q-1. \\
\hline $\mathrm{BM}_{\mathrm{q}-1}$ & $\begin{array}{l}\text { = ratio of common book equity to total market capitalization at the end of quarter q-1 } \\
\text { (DATA59/ (DATA14*DATA61)). }\end{array}$ \\
\hline RETQ1 $_{\mathrm{q}}$ & $\begin{array}{l}\text { = daily buy-and-hold returns over one calendar quarter prior to the calendar quarter } \mathrm{q} \\
\text { (i.e., from the end of calendar quarter q- } 2 \text { to the end of q-1). }\end{array}$ \\
\hline RETQ24 $_{\mathrm{q}}$ & $\begin{array}{l}=\text { daily buy-and-hold returns over calendar quarters } 2 \text { to } 4 \text { prior to the calendar } \\
\text { quarter q (i.e., from the end of calendar quarter q-5 to the end of q-2). }\end{array}$ \\
\hline $\mathrm{UE}_{\mathrm{q}-1}$ & $\begin{array}{l}\text { =seasonal unexpected earnings per share before extraordinary items (DATA9) in } \\
\text { quarter q-1, measured by the change in earnings per share before extraordinary items } \\
\text { from fiscal quarter q- } 5 \text { to q-1, scaled by the ending price of fiscal quarter q- } 2 \text {. }\end{array}$ \\
\hline Industry dummies & $\begin{array}{l}\text { = defined by the following SIC codes adapted from Barth, Beaver and Landsman } \\
\text { (1999): mining, construction and extractive industry (1000-1999, 2900-2999); food, } \\
\text { textiles, chemicals and pharmaceuticals (2000-2111, 2200-2799, 2800-2824, 2830- } \\
2836,2840-2899) \text {; manufacturers and computers }(3000-3999,7370-7379) \text {; utilities } \\
\text { and transportation (4000-4899, 4900-4999); retail (5000-5999); financial services } \\
(6000-6411,6500-6999) \text {; service }(7000-7369,7380-8999) \text {. }\end{array}$ \\
\hline \multicolumn{2}{|c|}{ Earnings manipulation variables } \\
\hline $\mathrm{DSRI}_{\mathrm{q}}$ & 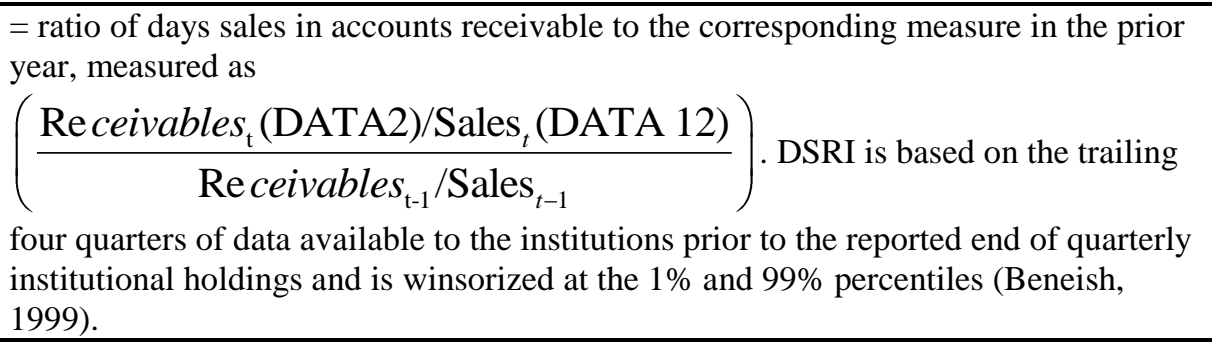 \\
\hline $\mathrm{GMI}_{\mathrm{q}}$ & $=$ ratio of gross margin percentage to the correspoinding measure in the prior year, \\
\hline
\end{tabular}




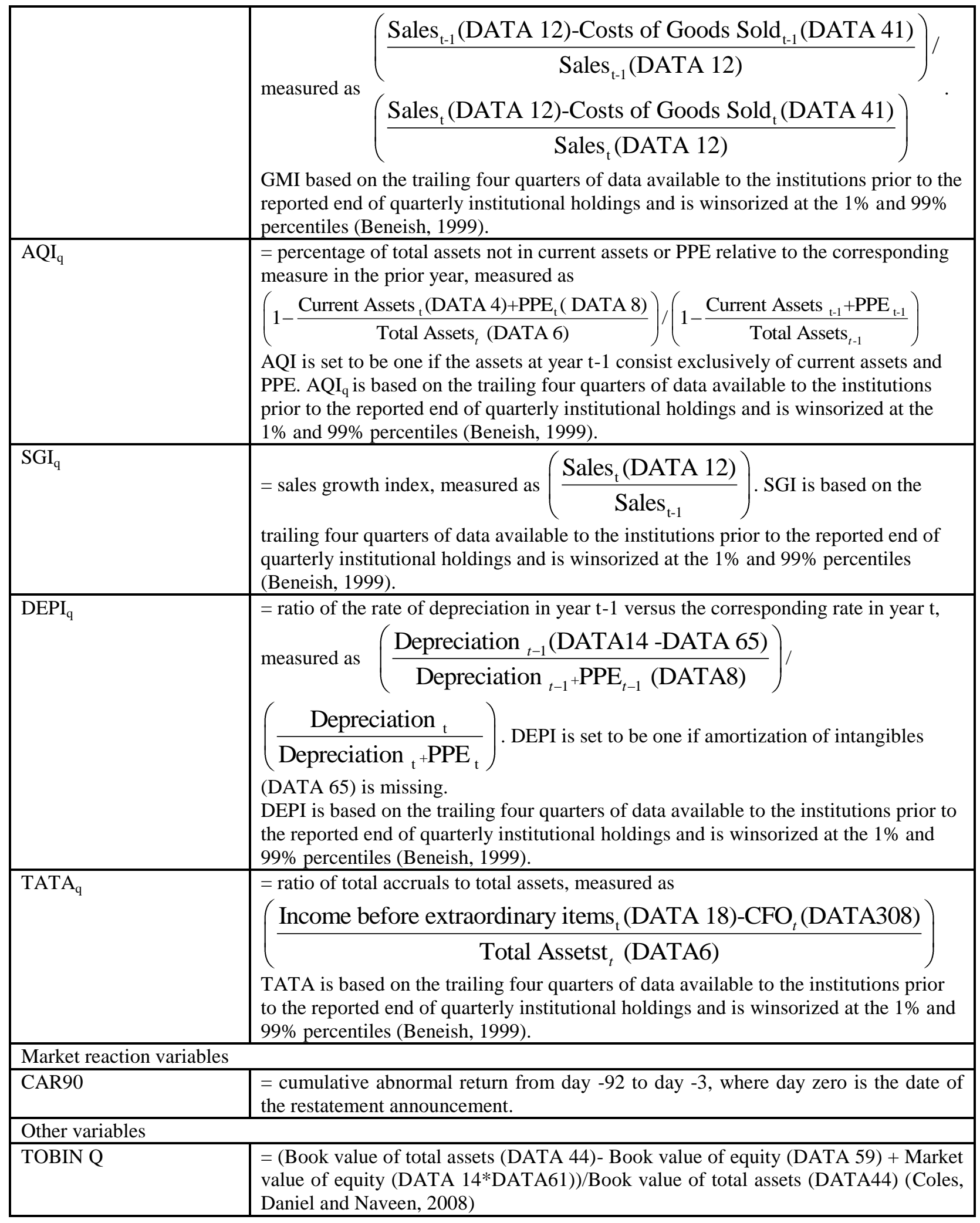

Appendix 2. Characteristics of Different Types of Institutions ${ }^{\text {abc }}$ 


\begin{tabular}{|l|l|l|l|l|}
\hline & & \multicolumn{1}{|c|}{ Transient } & \multicolumn{1}{c|}{ Dedicated } & \multicolumn{1}{c|}{ Quasi-indexers } \\
\hline Portfolio turnover factor & mean & 1.472 & -0.228 & -0.442 \\
\hline PT1 & mean & 0.774 & 0.414 & 0.368 \\
\hline PT2 & mean & 0.557 & 0.231 & 0.229 \\
\hline STAB1 & mean & 0.335 & 0.578 & 0.569 \\
\hline STAB2 & mean & 0.461 & 0.713 & 0.700 \\
\hline Portfolio concentration factor & mean & -0.196 & 2.122 & -0.292 \\
\hline LBPH & mean & 0.032 & 0.382 & 0.026 \\
\hline LBPF & mean & 0.014 & 0.213 & 0.009 \\
\hline APH & mean & 0.009 & 0.063 & 0.008 \\
\hline CONC & mean & 5.910 & 14.772 & 5.817 \\
\hline
\end{tabular}

Description for the above table. ${ }^{a}$ This table is based on Table 1 of Bushee, B. (2001). Do institutional investors prefer near-term earnings over long-run value? Contemporary Accounting Research, 18, 207-246, and Table 5 of Bushee, B. (1998). The influence of institutional investors on myopic R\&D investment behavior. The Accounting Review, 305-333.

${ }^{\mathrm{b}}$ The classification of transient, dedicated, and quasi-indexing institutions is institution-year specific, based on a factor analysis and cluster analysis. First, a portfolio turnover factor (a portfolio concentration factor) is created based on the variables listed below the portfolio turnover factor (the portfolio concentration factor) in the table above. Next, a cluster analysis is performed to group institutions with similar turnover and concentration factor into transient, dedicated, and quasi-indexing institutions, respectively. The variables used in the factor analysis are calculated at the end of each calendar quarter for every institution on the SPECTRUM database. Quarterly values are averaged over all available quarters to calculate year-end values for each institution-year.

${ }^{\mathrm{c}}$ The above table indicates that transient institutions have short investment horizon (high turnover factor) and small stakes in portfolio firms (low concentration factor), suggesting that transient institutional investors trade actively over short-term to maximize trading profits. Dedicated institutions have long investment horizon (low turnover factor) and large stakes (high concentration factor) in portfolio firms, consistent with the "relationship investing" role. Quasi-indexers have long investment horizon (low turnover factor) and small stakes (low concentration factor) in portfolio firms, consistent with a passive buy-and-hold indexing strategy.

PT1 = institution's quarterly portfolio turnover percentage $=\sum\left|W_{k t}-W_{k t-1}\right| /\left(\sum W_{k t}+\sum W_{k, t-1}\right), W_{k t}$ is portfolio weight (shares held times stock price) in firm $\mathrm{k}$ at end of quarter $\mathrm{t}$.

PT2 = institution's quarterly portfolio turnover percentage using only sales transactions

STAB1 = percentage of the institution's holdings held continuously for two years $\left(=\left(\sum \boldsymbol{W k t} * \boldsymbol{L T k t}\right) / \sum \boldsymbol{W k t}\right.$, where Wkt=portfolio weight (shares held times stock price) in firm $\mathrm{k}$ at end of quarter $\mathrm{t}, \mathrm{LTkt}=1$ if the institution held firm $\mathrm{k}$ continuously for prior eight quarters, 0 otherwise)

STAB2 = percentage of the institution's portfolio firms held continuously for two years.

LBPH =percentage of the institution's holdings held in large blocks (greater than 5\%)

LBPF =percentage of the institution's portfolio firms held in large blocks (greater than 5\%)

$\mathrm{APH}=$ the institution's average percentage ownership in its portfolio firms.

$\mathrm{CONC}=$ the institution's average investment size in its portfolio firms (millions \$) 